\title{
Decanting of Neutralized H-Canyon Unirradiated Nuclear Material High Activity Waste Streams
}

\author{
By
}

Michael G. Bronikowski and John H. Gray

Issued: July 2004

Savannah River National Laboratory

Aiken, SC 29808

Prepared for the U.S. Department of Energy Under Contract Number

DEAC09-96SR18500

Savannah River National Laborabory

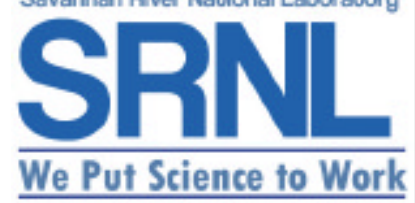


This document was prepared in conjunction with work accomplished under Contract No. DE-AC09-96SR18500 with the U. S. Department of Energy.

\section{DISCLAIMER}

This report was prepared as an account of work sponsored by an agency of the United States Government. Neither the United States Government nor any agency thereof, nor any of their employees, makes any warranty, express or implied, or assumes any legal liability or responsibility for the accuracy, completeness, or usefulness of any information, apparatus, product or process disclosed, or represents that its use would not infringe privately owned rights. Reference herein to any specific commercial product, process or service by trade name, trademark, manufacturer, or otherwise does not necessarily constitute or imply its endorsement, recommendation, or favoring by the United States Government or any agency thereof. The views and opinions of authors expressed herein do not necessarily state or reflect those of the United States Government or any agency thereof.

This report has been reproduced directly from the best available copy.

Available for sale to the public, in paper, from: U.S. Department of Commerce, National Technical Information Service, 5285 Port Royal Road, Springfield, VA 22161, phone: (800) 553-6847, fax: (703) 605-6900

email: orders@ntis.fedworld.gov

online ordering: http://www.ntis.gov/help/index.asp

Available electronically at http://www.osti.gov/bridge

Available for a processing fee to U.S. Department of Energy and its contractors, in paper, from: U.S. Department of Energy, Office of Scientific and Technical Information, P.O. Box 62, Oak Ridge, TN 37831-0062,

phone: (865)576-8401,

fax: (865)576-5728

email: $\underline{\text { reports@ adonis.osti.gov }}$ 
This page was intentionally left blank 


\section{Table of Contents}

Section

Page

Summary $\ldots 1$

Introduction. .2

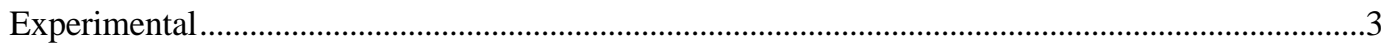

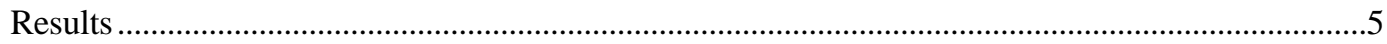

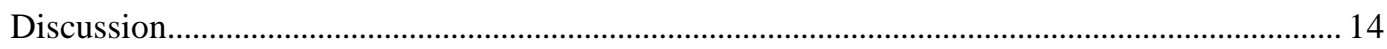

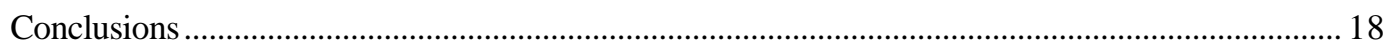

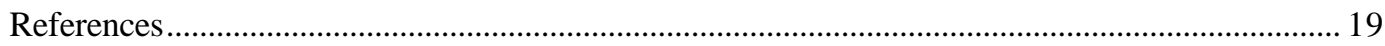

\section{List of Tables}



Table 2. Behavior of HAW \#1 Solution during $\mathrm{NaOH}$ Addition.........................................................

Table 3. Behavior of HAW \#2 Solution during $\mathrm{NaOH}$ Addition.........................................................

Table 4. Behavior of HAW \#3 Solution during $\mathrm{NaOH}$ Addition........................................................

Table 5. Characterization of Basic HAW \#1 Supernate and Slurry....................................................

Table 6. Characterization of Basic HAW \#2 Supernate and Slurry.................................................

Table 7. Characterization of Acidified HAW \#2 Settled Slurry........................................................

Table 8. Characterization of Basic HAW \#3 Supernate and Slurry ....................................................

Table 9. Characterization of Acidified HAW \#3 Settled Slurry......................................................... 10

Table 10. Settling Curve Fit Parameters...................................................................................... 13

Table 11. Viscosity Calibration and Basic Waste Results............................................................ 13

Table 12. Final Results for all Basic Waste Compared to the Proposed WAC limits.................... 15 
Figure 1. Settling Curve for HAW \#1 Solution.................................................................................. 10

Figure 2. Settling Curve for HAW \#2 Solution................................................................................ 11

Figure 3. Settling Curve for HAW \#3 Solution............................................................................... 11

Figure 4. Settling Curves for all Three Solutions Studied.............................................................. 12

Appendix A. List of Figures for Solids in Basic HAW \#1, HAW \#2, and HAW \#3 Solutions

Figure 1A Settling of Solids in Basic HAW \#1 and HAW \#2 Solutions........................................ A-1

Figure 2A Settling of Solids in Basic HAW \#1 and HAW \#2 Solutions...................................... A-1

Figure 3A Settling of Solids in Basic HAW \#1 and HAW \#2 Solutions...................................... A-2

Figure 4A SEM Spectra for Solids Suspended in Basic HAW \#2 Supernate …………………... A-3

Figure 5A SEM Spectra for Solids Suspended in Basic HAW \#2 Supernate ................................ A-4

Figure 6A Settling of Solids in Basic HAW \#3 Solutions ............................................................. A-5

Figure 7A Settling of Solids in Basic HAW \#3 Solutions........................................................... A-5

Figure 8A SEM Spectra for Solids Suspended in Basic HAW \#3 Supernates.............................. A-6

Appendix B Compilation of Raw Data Obtained from Analysis of Original and Basic ............... B-1 HAW \#1, HAW \#2, and HAW \#3 Solutions 
WSRC-TR-2004-00123

Revision 0

\title{
Decanting of Neutralized H-Canyon Unirradiated Nuclear Material High Activity Waste Streams
}

\author{
Michael G. Bronikowski and John H. Gray
}

\section{SUMMARY}

An option to dispose of the High Activity Waste (HAW) stream from the processing of unirradiated materials directly to Saltstone is being evaluated to conserve High Level Waste (HLW) tank farm space and to reduce the future production of HLW glass logs. To meet the Saltstone Waste Acceptance Criteria (WAC), decanting the supernate from precipitated solids was proposed to reduce mercury and radionuclide levels in the waste. Only the caustic supernate will then be sent to Saltstone. Verification that the Saltstone WAC will be met has involved a series of laboratory studies using surrogate and actual HAW solutions from H-Canyon.

The initial experiment involved addition of sodium hydroxide $(\mathrm{NaOH})$ to a surrogate $\mathrm{HAW}$ test solution and subsequent decanting of the supernate away from the precipitated solids. The chemical composition of the surrogate solution was based on a composition defined from analyses of actual HAW solutions generated during dissolution of unirradiated nuclear materials in H-Canyon [1]. Results from testing the surrogate HAW solution were reported in Reference [2].

Information obtained from the surrogate test solution study was used to define additional experiments on actual HAW solutions obtained from H-Canyon. These experiments were conducted with samples from three different batches of HAW solutions. The first and third HAW samples (HAW \#1 and HAW \#3 solutions) contained the centrifuge filter cake material from a gelatin strike that is periodically added to the waste stream. The second HAW sample (HAW \#2 solution) did not contain filter cake material. Monosodium titanate (MST) was added to the HAW \#2 and HAW \#3 solutions after addition of $\mathrm{NaOH}$ was complete and before the settling step. The addition of MST was to improve the decontamination of alpha and beta emitters (primarily plutonium and strontium) from the supernate. The addition of excess $\mathrm{NaOH}$ and the addition of MST were expected to result in sufficient alpha and beta decontamination to meet the Saltstone WAC.

The HAW solutions were made basic with $50 \mathrm{wt} \% \mathrm{NaOH}$ to $1.2 \mathrm{M}$ excess hydroxide before settling experiments were initiated. Differences observed in settling rates were explained by variations in the chemical composition of original HAW solutions, by the addition of MST, and by the digestion of the slurry at elevated temperatures before settling began.

Fluid transport properties, such as viscosity and density, were measured for the settled solids. The viscosities of the settled solids increased from $10 \pm 2$ centipoise after the HAW \#1 slurry had settled for 24 hours to $14 \pm 3$ centipoise after the HAW \#2 slurry had settled for 20 hours. The viscosity of the HAW \#3 settled solids was not measured. The densities of the settled solids increased from $1.355 \mathrm{~g} / \mathrm{cc}$ for HAW \#1, to $1.384 \mathrm{~g} / \mathrm{cc}$ for HAW \#2, and to $1.43 \mathrm{~g} / \mathrm{cc}$ for HAW \#3.

After combining dilution factors with the decontamination factors provided by addition of $\mathrm{NaOH}$ and by addition of MST, results showed that mercury, alpha radionuclides, and most fission product concentrations in the supernate met the Saltstone WAC. In addition, 85-95\% of the aluminum in the First Uranium Cycle Waste (1AW) stream will be soluble in the caustic supernate sent to Saltstone. Thus, the mass of aluminum 
that is normally sent to the High Level Waste (HLW) tank farm would now be significantly reduced. Additionally, the volume of waste going to the HLW evaporator would be reduced.

Changes to the chemical composition of the 1AW stream were implemented by H-Canyon to optimize the dissolution and solvent extraction operations. These changes in chemical composition may impact some of the decontamination factors needed by Saltstone to meet WAC concentration limits. In addition, the continued decline in residual contaminants that are WAC limiting at this time is expected as "cleaner" unirradiated fuel material is processed. This decline is expected to reduce the decontamination that is needed by decanting.

\section{INTRODUCTION}

The H-Canyon facility has begun dissolving unirradiated nuclear materials that contain enriched aluminum uranium alloy clad in aluminum. Normally the $1 \mathrm{AW}$ high activity waste stream that is generated from First Uranium Cycle solvent extraction operations would be made basic with $\mathrm{NaOH}$ to an excess of $1.2 \mathrm{M}$ hydroxide in the H-Canyon neutralization process and sent directly to the HLW tank farm. Howe ver, since this particular waste stream is not from the dissolution of spent nuclear fuel, it may not be required by regulation to be sent to the HLW tank farm; instead it could be sent to Saltstone provided the WAC for mercury, alpha radionuclides, fission products, and other constraints are satisfied.

The initial evaluation of the waste stream by H-Canyon indicated the Saltstone WAC would not be met [1]. Thus, it was proposed to determine if separation of the supernate from the solids by simple decanting would yield a solution that could meet the WAC. The diversion of this HAW stream to Saltstone conserves valuable HLW tank farm space, saves HLW evaporator usage, and reduces the quantity of glass logs produced in the Defense Waste Processing Facility.

The previous study using a surrogate HAW solution established the feasibility for decanting the supernate that could meet some of the Saltstone WAC [2]. To confirm that all Saltstone WAC criteria would be met with actual HAW solutions, three solutions with different compositions were provided by H-Canyon for characterization and decanting studies. Experiments were performed to investigate the precipitation of solids with $50 \mathrm{wt} \% \mathrm{NaOH}$ and to determine the settling characteristics of solids from the resulting supernates. The settling rate curves of solids from the slurries would provide settling times that would maximize the volume of supernate sent to Saltstone and minimize the volume of settled solids that would be sent to the HLW tank farm. In addition to characterization of the starting HAW solutions, characterization of supernates and settled solids as a function of settling times was performed to determine if sufficient decontamination had occurred. Viscosity measurements were performed on the settled solids phase for transport considerations.

Initially the use of MST was to lower the plutonium $(\mathrm{Pu})$ content in the HAW \#2 solution after the HAW \#1 supernate failed to meet the WAC for plutonium. Then MST was added to the HAW \#3 solution to improve the decontamination of strontium-90 ( $\mathrm{Sr}-90)$ from the supernate when total beta results from HAW \#1 and HAW \#2 experiments indicated the WAC for Sr-90 would not be met. The sources of fission products and transuranic elements found in unirradiated nuclear materials include the use of recycled uranium, spontaneous fission, and the use of equipment that was contaminated after years of irradiated fuel processing.

\section{EXPERIMENTAL}

\section{Characterization of H-Canyon HAW Solutions}

Since the dissolution of unirradiated nuclear materials has started in H-Canyon, the radioactivity levels and composition of the 1AW waste stream have changed. Thus three candidate HAW solutions were provided by H-Canyon for testing. After receipt of the HAW solutions, solution densities were determined by weighing a known volume of solution. One milliliter samples were taken and analyzed for total and free 
acid via titration, for chemical composition using Inductively Coupled Plasma - Emission Spectroscopy (ICP-ES), for mercury using Cold Vapor atomic absorption spectroscopy (CV-Hg), for total beta using Radscreen (Tk-50), for plutonium using plutonium triphenyltriflouroacetone analysis (PuTTA), for fission products using gamma spectroscopy, for transuranic isotopes using alpha pulse height analysis ( $\alpha$ PHA), and for Sr-90 involving a chemical separation step using ion exchange followed by liquid scintillation counting. Results from characterization studies of as-received HAW solutions are presented in Table 1.

Table 1. Characterization of H-Canyon HAW Solutions

\begin{tabular}{|c|c|c|c|}
\hline Analysis & $\begin{array}{c}\text { Original HAW \#1 } \\
\text { Solution (of 3/23) } \\
\text { (with filter cake) }\end{array}$ & $\begin{array}{c}\text { Original HAW \#2 } \\
\text { Solution (of 3/24) } \\
\text { (without filter cake) }\end{array}$ & $\begin{array}{c}\text { Original HAW \#3 } \\
\text { Solution (of 5/3) } \\
\text { (with filter cake) }\end{array}$ \\
\hline Density $\left(\mathrm{g} / \mathrm{cm}^{3}\right)$ & 1.265 & 1.329 & 1.23 \\
\hline Mercury $(\mathrm{ppm})$ & 892 & 867 & 714 \\
\hline Free Acid $(\mathrm{M})$ & 2.88 & $5.39(4.0)^{(*)}$ & 2.76 \\
\hline Total Acid (M) & 8.08 & 7.81 & 4.7 \\
\hline Aluminum (M) & 1.14 & 1.48 & 1.17 \\
\hline Total Alpha $(\mathrm{dpm} / \mathrm{ml})$ & ${ }^{(*)} 1.90 \times 10^{6}$ & ${ }^{(*)} 1.56 \times 10^{6}$ & $1.51 \times 10^{5}$ \\
\hline Pu alpha $(\mathrm{dpm} / \mathrm{ml})$ & Not Analyzed & Not Analyzed & $1.16 \times 10^{5}$ \\
\hline Total Beta $(\mathrm{dpm} / \mathrm{ml})$ & $2.38 \times 10^{8}$ & $1.24 \times 10^{8}$ & $2.81 \times 10^{7}$ \\
\hline Gamma Results $(\mathrm{dpm} / \mathrm{ml})$ & & & $1.23 \times 10^{4}$ \\
\hline Am-241 & $7.5 \times 10^{3}$ & $5.5 \times 10^{3}$ & $3.73 \times 10^{5}$ \\
\hline Cs-137 & $2.00 \times 10^{6}$ & $1.56 \times 10^{6}$ & $1.54 \times 10^{6}$ \\
\hline Sb-125 & $1.67 \times 10^{6}$ & $1.62 \times 10^{6}$ & $252 / 1027$ \\
\hline ICP-ES (ppm) & & & 12 \\
\hline Fe/Mn & $2,123 / 2,200$ & $2,816 / 51$ & 60.3 \\
\hline Uranium & 92 & 88 & 3,267 \\
\hline Sulfur & 2,530 & Not Analyzed & 4.63 \\
\hline Sodium & 6,259 & 4,037 & 4.44 \\
\hline Strontium & 5.61 & & \\
\hline
\end{tabular}

(*) The Quality Control analysis indicated that the $5.39 \mathrm{M}$ free acid result was too high. For all of the $1.48 \mathrm{M}$ aluminum to be soluble, the maximum nitric acid concentration can be $4 \mathrm{M}$. Therefore, the final excess hydroxide molarity was recalculated to be $1.3 \mathrm{M}$ based on the aluminum solubility limit in $4 \mathrm{M}$ nitric acid.

$(\dagger)$ Most total alpha activities in HAW \#1 and HAW \#2 solutions are biased high due to beta "spillover" into the alpha spectrum.

The 1-ml samples taken for analysis from each HAW solution were added to $10 \mathrm{ml}$ of either de-ionized water or low molar nitric acid. The sample analysis results reported in Table 1 reflect the dilution factor of 11 that was applied to the raw data presented in Appendix B.

\section{$\underline{\mathrm{NaOH} \text { Addition and Precipitation }}$}

The neutralization of free acid, the precipitation of solids, and the formation of the aluminum complex were performed by the addition of $30 \mathrm{ml}$ of $50 \mathrm{wt} \% \mathrm{NaOH}$ to $61 \mathrm{ml}$ of the HAW \#1 solution, by the addition of $43 \mathrm{ml}$ of $50 \mathrm{wt} \% \mathrm{NaOH}$ to $63 \mathrm{ml}$ of HAW \#2 solution, and by the addition of $26 \mathrm{ml}$ of $50 \mathrm{wt} \% \mathrm{NaOH}$ to $54 \mathrm{ml}$ of $\mathrm{HAW} \# 3$ solution. The volume of $\mathrm{NaOH}$ required to reach approximately $1.2 \mathrm{M}$ excess hydroxide $\left(\mathrm{OH}^{-}\right)$in all solutions was based on the concentration information provided in Table 1. First, sufficient $\mathrm{NaOH}$ was added to neutralize the hydrogen ions $\left(\mathrm{H}^{+}\right)$shown as free acid in Table 1. Second, enough $\mathrm{NaOH}$ was added to hydrolyze the metal ions in the original solution. This $\mathrm{NaOH}$ precipitated $\sim 5-15 \%$ of the $\mathrm{Al}^{3+}$ as $\mathrm{Al}(\mathrm{OH})_{3}$, converted $~ 85-95 \%$ of the $\mathrm{Al}^{3+}$ to the soluble complex $\mathrm{AlO}_{2}{ }^{-} \bullet 2 \mathrm{H}_{2} \mathrm{O}\left(\right.$ or $\left.\mathrm{Al}(\mathrm{OH})_{4}{ }^{-}\right)$, precipitated $\mathrm{Hg}^{2+}$ as $\mathrm{HgO}, \mathrm{Hg}_{(1)}$, etc, and precipitated $\mathrm{Fe}^{3+}, \mathrm{Mn}^{2+}$, and other minor transition metal ions as insoluble hydroxides. Then the additional $\mathrm{NaOH}$ needed to reach an excess hydroxide concentration of $1.2 \mathrm{M}$ was added. 
The starting volumes of each HAW solution were measured in a graduated cylinder. The HAW solutions were transferred to $250-\mathrm{ml}$ beakers for the addition of $50 \mathrm{wt} \% \mathrm{NaOH}$. Addition of $\mathrm{NaOH}$ was performed using calibrated pipettes. The HAW solutions were mixed with a magnetic stirrer, and by hand when the precipitate "thickened". Brown or black precipitates formed immediately upon addition of the first few milliliters of $\mathrm{NaOH}$. The solution temperature during neutralization of the HAW \#1 solution was allowed to vary freely as long as it remained below $60^{\circ} \mathrm{C}$. The addition rate of $\mathrm{NaOH}$ during the $\mathrm{H}$-Canyon neutralization process is controlled to maintain solution temperatures below $60^{\circ} \mathrm{C}$. There was no need to slow the $\mathrm{NaOH}$ addition rate to control the temperature in HAW \#1, as the temperature never reached $50{ }^{\circ} \mathrm{C}$. The solution temperature during neutralization of HAW \#2 and HAW \#3 solutions was maintained between $40-45^{\circ} \mathrm{C}$ by using a hot plate. Other than this temperature variation, all $\mathrm{NaOH}$ additions were performed under identical conditions. Run conditions and observations noted during the addition of $\mathrm{NaOH}$ to the HAW solutions are summarized in Table 2, 3, and 4.

Table 2. Behavior of HAW \#1 Solution during $\mathrm{NaOH}$ Addition.

\begin{tabular}{|c|c|c|c|c|}
\hline \multicolumn{5}{|c|}{ Study Conditions: $61 \mathrm{ml} \mathrm{HAW} \mathrm{\# 1,} \mathrm{Initial} \mathrm{Soln.} \mathrm{Temp.} \sim 22^{\circ} \mathrm{C}$} \\
\hline Time & $\begin{array}{l}\text { Addition Rate } \\
(\mathrm{ml})\end{array}$ & $\mathrm{pH}$ & $\begin{array}{c}\text { Solution } \\
\text { Temperature } \\
\left({ }^{\circ} \mathrm{C}\right)\end{array}$ & Observations \\
\hline 7:00 & +2 & $<1$ & 24 & few brown and black solids \\
\hline 7:05 & +3 & $<1$ & 27 & white, brown, and black solids \\
\hline $7: 10$ & +3 & 2 & 30 & more solids \\
\hline $7: 15$ & +3 & 3 & 36 & more white solids \\
\hline $7: 20$ & +2 & 3 & 33 & full of solids, stirring easy \\
\hline $7: 25$ & +2 & 3 & 32 & solids thick \\
\hline $7: 30$ & +1 & $7-8$ & 30 & hand stirred, thick \\
\hline $\mathrm{NaOH} \mathrm{ml}$ added & +16 & & & \\
\hline $7: 35$ & +1 & 8 & 28 & easy to stir \\
\hline $7: 40$ & +1 & $>11$ & 27 & fast stirring \\
\hline $7: 45$ & +1 & $>11$ & 26 & fast stirring \\
\hline $7: 50$ & +2 & $>11$ & 26 & fast stirring \\
\hline $7: 55$ & +2 & $>11$ & 26 & fast stirring \\
\hline $\mathrm{NaOH} \mathrm{ml}$ added & +24 & \multicolumn{3}{|c|}{ calculated $\mathrm{OH}^{-}$equivalents added, ready for excess $\mathrm{NaOH}$ addition } \\
\hline $8: 10$ & +3 & & & \\
\hline $8: 15$ & +3 & & & \\
\hline Total $\mathrm{ml}$ added & +30 & \multicolumn{3}{|c|}{$\begin{array}{l}30 \mathrm{ml} \text { equals } \sim 1.2 \mathrm{M} \text { excess hydroxide } \\
\text { for a } 1.49 \mathrm{NaOH} \text { addition dilution ratio }\end{array}$} \\
\hline $8: 25$ & $1 \mathrm{HAW}$ & lurry a & to cylinder to & egin settling study \\
\hline
\end{tabular}


Table 3. Behavior of HAW \#2 Solution during $\mathrm{NaOH}$ Addition.

\begin{tabular}{|c|c|c|c|c|}
\hline \multicolumn{5}{|c|}{ 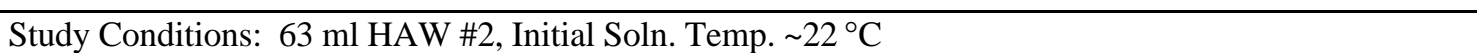 } \\
\hline Time & $\begin{array}{l}\text { Addition Rate } \\
\quad(\mathrm{ml})\end{array}$ & $\mathrm{pH}$ & $\begin{array}{c}\text { Solution } \\
\text { Temperature } \\
\left({ }^{\circ} \mathrm{C}\right)\end{array}$ & Observations \\
\hline $6: 50$ & +5 & $<1$ & 33 & few brown solids \\
\hline $6: 55$ & +5 & $<1$ & 36 & white, brown solids \\
\hline $7: 00$ & +3 & 3 & 41 & more solids \\
\hline $7: 05$ & +3 & 3 & 42 & many solids, more white solids \\
\hline $7: 10$ & +3 & 3 & 42 & full of solids, stirring easy \\
\hline $7: 15$ & +2 & 3 & 39 & still stirring \\
\hline $7: 20$ & +2 & $4-5$ & 40 & slow stirring \\
\hline $\mathrm{NaOH} \mathrm{ml}$ added & +23 & & & \\
\hline $7: 27$ & +2 & 10 & 44 & all easy to stir \\
\hline $7: 35$ & +2 & 11 & 42 & easy to stir \\
\hline $7: 40$ & +3 & $>11$ & 42 & fast stirring \\
\hline $7: 45$ & +3 & $>11$ & 42 & fast stirring \\
\hline $7: 50$ & +3 & $>11$ & 45 & fast stirring \\
\hline $\mathrm{NaOH} \mathrm{ml}$ added & +36 & \multicolumn{3}{|c|}{ calculated $\mathrm{OH}^{-}$equivalents added, ready for excess $\mathrm{NaOH}$ addition } \\
\hline $8: 00$ & +7 & & & MST slurry added to HAW \#2 \\
\hline Total $\mathrm{ml}$ added & +43 & \multicolumn{3}{|c|}{$\begin{array}{l}43 \mathrm{ml} \text { equals } \sim 1.2 \mathrm{M} \text { excess hydroxide } \\
\text { for a } 1.68 \mathrm{NaOH} \text { addition dilution ratio }\end{array}$} \\
\hline 8:00 & \multicolumn{4}{|c|}{$\mathrm{HAW} \# 2+\mathrm{MST}$ mixed at $45^{\circ} \mathrm{C}$ for $3.5 \mathrm{hrs}$} \\
\hline $11: 45$ & \multicolumn{4}{|c|}{$100 \mathrm{ml}$ HAW \#2 slurry added to cylinder to begin settling study } \\
\hline
\end{tabular}

Table 4. Behavior of HAW \#3 Solution during $\mathrm{NaOH}$ Addition.

\begin{tabular}{|c|c|c|c|c|}
\hline \multicolumn{5}{|c|}{  } \\
\hline Time & $\begin{array}{c}\text { Addition } \\
\text { Rate } \\
(\mathrm{ml})\end{array}$ & $\mathrm{pH}$ & $\begin{array}{c}\text { Solution } \\
\text { Temperature } \\
\left({ }^{\circ} \mathrm{C}\right)\end{array}$ & Observations \\
\hline $6: 47$ & +3 & $<1$ & 24 & few black solids \\
\hline $6: 55$ & +3 & $<1$ & 30 & mor black solids \\
\hline $7: 00$ & +2 & 3 & 31 & more white solids \\
\hline $7: 05$ & +1 & 3 & 40 & white and black solids \\
\hline $7: 12$ & +1 & $3-4$ & 43 & full of solids, stirring easy \\
\hline $7: 18$ & +2 & 4 & 42 & hand stirring \\
\hline $7: 25$ & +2 & 9 & 42 & easy to stir \\
\hline $\mathrm{NaOH} \mathrm{ml}$ added & +14 & & & \\
\hline $7: 34$ & +2 & $>11$ & 47 & easy to stir \\
\hline $7: 45$ & +2 & $>11$ & 48 & easy to stir \\
\hline $7: 50$ & +3 & $>11$ & 50 & fast stirring \\
\hline $\mathrm{NaOH} \mathrm{ml}$ added & +21 & \multicolumn{3}{|c|}{ calculated $\mathrm{OH}^{-}$equivalents added, ready for excess $\mathrm{NaOH}$ addition } \\
\hline $7: 55$ & +5 & & 50 & \\
\hline Total $\mathrm{ml}$ added & +26 & \multicolumn{3}{|c|}{$\begin{array}{l}26 \mathrm{ml} \text { equals } \sim 1.2 \mathrm{M} \text { excess hydroxide } \\
\text { for a } 1.48 \mathrm{NaOH} \text { addition dilution ratio }\end{array}$} \\
\hline $8: 30$ & \multicolumn{4}{|c|}{ Samples pulled first, MST added, mixed at $45^{\circ} \mathrm{C}$ for $4 \mathrm{hrs}$. } \\
\hline $12: 30$ & \multicolumn{4}{|c|}{72 ml HAW \#3 slurry added to cylinder to begin settling study } \\
\hline
\end{tabular}


WSRC-TR-2004-00123

Revision 0

\section{Settling of HAW Solids}

After addition of $\mathrm{NaOH}$ to the HAW \#1 solution was complete, the caustic slurry was agitated and transferred to a 250-ml graduated cylinder to begin the settling study. Slurries of MST ( $0.16 \mathrm{~g}$ MST were added to the HAW \#2 solution and $0.04 \mathrm{~g}$ MST were added to the HAW \#3 solution) were added to beakers c ontaining the HAW \#2 and HAW \#3 slurries after the addition of $\mathrm{NaOH}$ was complete. The slurries containing the MST were agitated and maintained at $45^{\circ} \mathrm{C}$ for approximately four hours before the slurries were transferred to graduated cylinders for the settling study. A set of samples were removed from the HAW \#3 slurry at time zero before the MST was added and digested for four hours.

The height of settled solids or the solid-liquid interface was recorded every half-hour visually, and by camera every hour during the night. Intermediate supernate samples were removed after three and seven hours from the basic HAW \#1 solution, after four hours from the basic HAW \#2 solution, and after zero and 3.5 hours from the basic HAW \#3 solution. To have representative samples of the supernate, most samples were taken approximately in the center of the supernate region. Care was taken so as not to mix the supernate or disturb the slurry-liquid interface while sampling. Final supernate samples were taken at the completion of the settling study. Intermediate and final supernate samples were submitted for analysis to determine soluble concentrations as a function of time. Small, fine brown solids remained suspended in the supernate at the completion of the settling experiments. A sample of the supernate was filtered and the suspended solids were analyzed by Scanning Electron Microscopy (SEM) to determine the elemental composition.

\section{Density of Supernates and Slurries}

The final densities of supernates and settled slurry solids were determined gravimetrically at the end of each settling experiment. Ten milliliters of supernate were pipetted with a 5.000-ml Gilman pipette into a tared graduated cylinder and the weight of each sample was measured using a calibrated balance. The final slurry densities were determined using the same gravimetric approach. In addition, the weight percent of suspended solids was determined and dried solids were analyzed by SEM. Data from supernates, settled solids, and suspended solids are summarized in Tables 5, 6, 7, 8, and 9 in the Results section.

\section{$\underline{\text { Viscosity of Settled Solids }}$}

The viscosities for the settled solids from the first two HAW basic slurries were measured. A modified Cannon-Ubbelohde viscometer was used to make the measurement on $\sim 14 \mathrm{ml}$ of the settled solids. Water, 1 wt $\%$ sodium nitrate $\left(\mathrm{NaNO}_{3}\right), 30 \mathrm{wt} \% \mathrm{NaNO}_{3}, 2$ wt $\% \mathrm{NaOH}, 10$ wt $\% \mathrm{NaOH}, 30$ wt $\% \mathrm{NaOH}$, and 50 wt $\% \mathrm{NaOH}$, were also measured to produce calibration curves. Only the viscosity of the HAW \#3 basic slurry that was remixed after 20 plus hours of settling time was measured. Insufficient settled solids were generated during $\mathrm{NaOH}$ addition to the $\mathrm{HAW} \# 3$ solution to allow a viscosity measurement to be performed on the settled solids.

The Cannon-Ubbelohde viscometer was chosen to measure the viscosity of settled solids, remixed slurry and solutions due to the small sample size required, its ease of use, and its availability. Usual viscosity measurement methods used at Savannah River National Laboratory require a minimum volume of $30 \mathrm{ml}$ to $70 \mathrm{ml}$ of sample. As the expected amount of solids was in the 20 to $25-\mathrm{ml}$ range, the 13 to $15-\mathrm{ml}$ sample size required for measurement, fit the viscometer well. A Cannon-Ubbelohde viscometer simply measures the time it takes for a known quantity of solution to pass through a capillary or the efflux time. The time is correlated to the viscosity via the viscometer constant. For the measurement made here, a size \#200 viscometer was used with a 0.1 centistokes/sec constant. The \#200 viscometer was used because it was available and the capillary bore size appeared large enough to allow the settled solids to flow through as a Newtonian fluid. The viscometer was modified to facilitate its use in a radiohood by adding a large bore stopcock on the draining tube. The stopcock bore was large enough to allow free flow draining by gravity. 
WSRC-TR-2004-00123

Revision 0

\section{RESULTS}

$\underline{\text { Visual Observations during Settling of HAW \#1 and HAW \#2 Slurries }}$

Photographs taken during settling of the basic HAW \#1 and HAW \#2 slurries are presented in Appendix A. The photographs in Figure 1A are representative of the early settling behavior of HAW \#1 and HAW \#2 slurries. Both slurries have suspended solids in the supernates. After the HAW \#1 slurry settled for 2.5 hours, the interface between supernate and slurry is clear. However, the HAW \#2 interface between the supernate and slurry is difficult to observe after $\sim 1.5$ hours settling time. A flashlight was needed to estimate the HAW \#2 interface at $72-73 \mathrm{ml}$ after 1.5 hours.

The photographs presented in Figure 2A represent intermediate settling times for the HAW \#1 and HAW \#2 solutions. The interface between supernate and slurry is easier to see in both solutions. Both solutions still have suspended solids in the supernates after eight to nine hours settling time. The weight percent of suspended solids was determined only in the intermediate sample taken from HAW \#2 supernate after four hours settling time.

The photographs shown in Figure 3A represent the final photographs taken for each solution. The camera taking pictures of neutralized HAW \#1 solution failed after $\sim 13$ hours settling time. The final supernate/slurry interface was visually recorded at $23 \mathrm{ml}$ ( $27 \%$ of total volume) after 24 hours settling time. Characterization of the HAW \#2 suspended solids filtered after 4 hours and 20 hours was determined using SEM. The determination of the weight percent of suspended solids was performed on samples taken at the completion of both settling studies.

\section{$\underline{\mathrm{NaOH} \text { Addition and Precipitation Tests of HAW \#1 and HAW \#2 }}$}

Results from analysis of supernate samples are presented in Tables 5 and 6. The significant difference after the addition of $\mathrm{NaOH}$ to the HAW \#1 and HAW \#2 solutions was the addition of MST to the HAW \#2 solution and the digestion for about four hours at $45^{\circ} \mathrm{C}$ before settling studies began. This difference could be used to explain the higher concentrations of both mercury and aluminum in the HAW \#2 supernates at the end of the settling periods. No significant difference in radiochemical concentrations was observed between the two supernates. Both observations and calculations of weight percent suspended solids confirmed that more suspended solids were present in the HAW \#2 supernate.

Results from analysis of slurry samples are presented in Tables 5, 6, and 7. The viscosity of $10 \pm 2$ centipoise in HAW \#1 slurry increased to $14 \pm 3$ centipoise in HAW \#2 slurry. The HAW \#1 slurry contained $\sim 44 \mathrm{wt} \%$ solids and therefore $\sim 56 \mathrm{wt} \%$ liquid. A similar result could not be obtained directly for the HAW \#2 settled slurry due to difficulty in drying the 1-ml slurry sample under ambient conditions. The upper limit of $48.5 \mathrm{wt} \%$ (Table 6) solids in the settled slurry was calculated based on ICP-ES concentration data. The 1-ml slurry sample was subsequently dissolved in $4 \mathrm{M}$ nitric acid and analyzed for radiochemical content. The analysis results presented in Table 7 confirmed that most of the alpha and beta radionuclides concentrate in the settled slurry and most of the cesium-137 and antimony-125 remain in the supernate.

\section{$\underline{\text { SEM Analysis of HAW \#1 and HAW \#2 }}$}

Results from SEM analysis of solids filtered from the 4 hour and 20 hour HAW \#2 supernate samples are presented in Figures 4A and 5A. Suspended solids with and without mercury were identified in both HAW \#2 samples. However, because the actual weight percent of solids in the supernates is small, any additional contribution to the amount of mercury in solution sent to Saltstone is not significant. Both HAW \#1 and HAW \#2 mercury concentrations in the supernates will be well below the Saltstone WAC. 
Table 5. Characterization of Basic HAW \#1 Supernate and Slurry.

\begin{tabular}{|c|c|c|c|}
\hline \multirow{2}{*}{\multicolumn{4}{|c|}{ 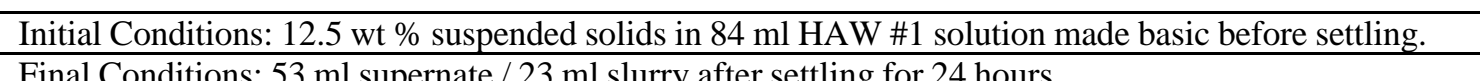 }} \\
\hline & & & \\
\hline Analysis & 3 Hour Supernate & 7 Hour Supernate & $\begin{array}{l}\text { 24 Hour Supernate and } \\
\text { Slurry if noted }\end{array}$ \\
\hline Mercury (ppm) & $<1.2$ (filtered) & $<1.2$ (filtered) & $\begin{array}{l}<1.2, \text { remaining } \mathrm{Hg} \\
\text { expected in the slurry }\end{array}$ \\
\hline Aluminum $(\%$ soluble, $\mathrm{M})$ & $84.6,0.70$ (filtered) & $85.6,0.73$ (filtered) & $86.1,0.78$ (filtered) \\
\hline Total alpha, $(\mathrm{dpm} / \mathrm{ml})$ & $<1.5 \times 10^{4}$ & $<2.9 \times 10^{4}$ & $<1.32 \times 10^{4}$ \\
\hline $\mathrm{Pu}$ alpha, $(\mathrm{dpm} / \mathrm{ml})$ & $1.47 \times 10^{3}$ & $1.39 \times 10^{3}$ & ${ }^{(*)}<3.45 \times 10^{4}$ \\
\hline Total Beta, $(\mathrm{dpm} / \mathrm{ml})$ & $2.36 \times 10^{6}$ & NA & $2.05 \times 10^{6}$ \\
\hline \multicolumn{4}{|l|}{ Gamma Scan $(\mathrm{dpm} / \mathrm{ml})$} \\
\hline Cs-137 & $1.33 \times 10^{6}$ & NA & $1.35 \times 10^{6}$ \\
\hline Sb-125 & $3.6 \times 10^{5}$ & NA & $3.9 \times 10^{5}$ \\
\hline $\mathrm{Fe} / \mathrm{Mn} / \mathrm{S}(\mathrm{ppm})$ & $12 / 18 / \mathrm{NA}$ & $10.6 / 16 / \mathrm{NA}$ & 7.8/9.6/NA \\
\hline Density $\left(\mathrm{g} / \mathrm{cm}^{3}\right)$ & NA & $\mathrm{NA}$ & $\begin{array}{c}1.31 \\
1.355 \text { slurry }\end{array}$ \\
\hline Viscosity (Centipoise) & NA & NA & $10 \pm 2$ slurry \\
\hline Suspended Solids (wt \%) & NA & NA & 0.428 \\
\hline Slurried solids (wt \%) & NA & NA & 43.7 solids in slurry \\
\hline
\end{tabular}

(*) The large minimum detection limit is due to neutralization with excess nitric acid after samples were taken.

Table 6. Characterization of Basic HAW \#2 Supernate and Slurry.

\begin{tabular}{|c|c|c|}
\hline \multicolumn{3}{|c|}{$\begin{array}{l}\text { Initial Conditions: } 8.5 \mathrm{wt} \% \text { suspended solids in } 100 \mathrm{ml} \mathrm{HAW} \mathrm{\# 2} \mathrm{solution} \mathrm{m} \\
\text { Final Conditions: } 75 \mathrm{ml} \text { supernate / } 17 \mathrm{ml} \text { slurry after settling for } 20 \text { hours. }\end{array}$} \\
\hline Analysis & 4 Hour Supernate & 20 Hour Supernate and Slurry if noted \\
\hline Mercury (ppm) & 72.8 (filtered) & 86.8 (filtered) \\
\hline Aluminum $(\%$ soluble, $\mathrm{M})$ & $94.8,0.98$ (filtered) & $98.5,1.0$ (filtered) \\
\hline Total alpha, $(\mathrm{dpm} / \mathrm{ml})$ & $\begin{aligned} & <1.54 \times 10^{4}(\text { filtered }) \\
< & 2.85 \times 10^{4}(\text { not filtered })\end{aligned}$ & $\begin{array}{l}<1.32 \times 10^{4}(\text { filtered }) \\
<1.5 \times 10^{4}(\text { not filtered })\end{array}$ \\
\hline $\mathrm{Pu}$ alpha, $(\mathrm{dpm} / \mathrm{ml})$ & $\begin{array}{l}3.76 \times 10^{3}(\text { filtered }) \\
1.92 \times 10^{4}(\text { not filtered })\end{array}$ & $\begin{array}{c}4.60 \times 10^{3}(\text { filtered }) \\
5.37 \times 10^{3}(\text { not filtered })\end{array}$ \\
\hline Total Beta (dpm/ml) & $\begin{array}{c}1.56 \times 10^{6}(\text { filtered }) \\
2.54 \times 10^{6}(\text { not filtered })\end{array}$ & $\begin{array}{c}1.52 \times 10^{6}(\text { filtered }) \\
1.96 \times 10^{6}(\text { not filtered })\end{array}$ \\
\hline \multicolumn{3}{|l|}{ Gamma Scan (dpm/ml) } \\
\hline Cs-137 (*) & $\begin{array}{c}1.0 \times 10^{6}(\text { filtered }) \\
7.96 \times 10^{5}(\text { not filtered })\end{array}$ & $\begin{array}{c}9.9 \times 10^{5}(\text { filtered }) \\
7.47 \times 10^{5}(\text { not filtered })\end{array}$ \\
\hline Sb-125 (*) & $\begin{array}{l}3.29 \times 10^{5}(\text { filtered }) \\
2.41 \times 10^{5}(\text { not filtered })\end{array}$ & $\begin{array}{c}3.2 \times 10^{5}(\text { filtered }) \\
2.25 \times 10^{5}(\text { not filtered })\end{array}$ \\
\hline \multicolumn{3}{|l|}{ ICP-ES (ppm) } \\
\hline $\mathrm{Fe} / \mathrm{Mn} / \mathrm{S}(\mathrm{ppm})$ & $1.4 /<0.2 / 1727$ ( not filtered ) & $1.1 /<0.2 / 1749$ ( not filtered $)$ \\
\hline Density $\left(\mathrm{g} / \mathrm{cm}^{3}\right)$ & NA & $\begin{array}{l}1.41 \text { (not filtered ) } \\
1.384 \text { slurry }\end{array}$ \\
\hline Viscosity (Centipoise) & NA & $14 \pm 3$ slurry \\
\hline Suspended Solids (wt \%) & 1.39 & 0.532 \\
\hline Slurried solids (wt \%) & NA & $<48.5$ solids in slurry \\
\hline
\end{tabular}

*The reason for the inverse concentrations of Cs-137 and Sb-125 isotopes between filtered and unfiltered solutions has not been identified. 
WSRC-TR-2004-00123

Revision 0

Table 7. Characterization of Acidified HAW \#2 Settled Slurry.

\begin{tabular}{|c|c|}
\hline \multicolumn{2}{|c|}{ Characterization of Solids in HAW \#2 Slurry } \\
\hline Run Conditions: 1 -ml slurry dissolved in 30 ml of $4 \mathrm{MNO}_{3}$ \\
\hline Analysis & 20 Hour Slurry \\
\hline Total alpha $(\mathrm{dpm} / \mathrm{ml})$ & $1.98 \times 10^{6}$ \\
\hline Pu alpha $(\mathrm{dpm} / \mathrm{ml})$ & $1.62 \times 10^{6}$ \\
\hline Total Beta $(\mathrm{dpm} / \mathrm{ml})$ & $3.81 \times 10^{8}$ \\
\hline Gamma Scan $(\mathrm{dpm} / \mathrm{ml})$ & \\
\hline $\mathrm{Cs}-137$ & $3.0 \times 10^{6}$ \\
\hline $\mathrm{Sb}-125$ & $8.7 \times 10^{5}$ \\
\hline
\end{tabular}

\section{$\mathrm{NaOH}$ and MST Addition to the HAW \#3 Solution}

The content and test conditions for the HAW \#3 sample were intended to represent most of the future dissolution and neutralization operations of unirradiated fuel in H-Canyon. The addition of filter cake material to this HAW \#3 batch of solution is a possible explanation for the manganese content due to a manganese neutron poison addition. The low iron content represents elimination of ferrous sulfamate during solvent extraction operations. The addition of $0.4 \mathrm{~g} /$ liter of MST to the supernate after making the solution basic and before settling was intended to evaluate the effectiveness of MST in removing additional Sr-90 from the supernate. However, due to the amount of suspended solids dissolved in the supernate samples, the individual concentrations of Sr-90 removed by MST and removed by the settling of suspended solids could not be separated.

\section{Visual Observations during Settling of the Basic HAW \#3 Slurry}

Photographs taken during settling of the basic HAW \#3 slurry are presented in Figures 6A and 7A. The solids that remained suspended after one hour settling time were so dark and thick that the liquid/solid interface cannot be clearly observed in Figure 6A HAW \#3 after 1 hour settling. The weight percent of suspended solids at this time is approaching the maximum weight percent of suspended solids (Table 8) that would be present in the agitated supernate just after addition of $50 \mathrm{wt} \% \mathrm{NaOH}$ has been completed. The liquid-solid interface observed at $15 \mathrm{ml}$ ( $20 \%$ of total volume) in Figure 6A for HAW \#3 after 2 hours settling represents the first photograph taken where the interface can be clearly observed.

The photograph of the basic HAW \#3 shown in Figure 7A after 3.5 hour settling was taken just after the 3.5 hour supernate samples were taken for analysis. The amount of suspended solids in the supernate at this time was about one-half the amount seen in the time zero samples. The last photograph in Figure 7A was taken after 20 hours of settling time. The final liquid/solid interface can be clearly seen at $6 \mathrm{ml}$ ( $\sim 8 \%$ of total volume).

\section{$\mathrm{NaOH}$ Addition and Precipitation Testing of the HAW \#3 Solution}

Results obtained from analysis of the supernate and slurry after HAW \#3 was made basic and settled are presented in Table 8 and Table 9. Greater than $90 \%$ of the aluminum will be in the supernate after $\mathrm{NaOH}$ addition to 1.2 molar excess. The mercury concentration in the supernate is less than $3 \mathrm{ppm}$. Most of the mercury has concentrated in the settled solids. The high concentration of mercury in the settled solids is one reason to limit the amount of solids remaining in the supernate sent to Saltstone. The solubility of both iron and manganese is sufficiently low to reduce the concentration of iron and manganese remaining in the supernate to a few ppm.

Most of the alpha and beta emitters have concentrated in the settled solids. The total beta concentration remaining in the supernate after the addition of $\mathrm{NaOH}$ is complete is between $1-2 \times 10^{6} \mathrm{dpm} / \mathrm{ml}$. The Sr-90 contribution to the total beta in the supernate samples after 3.5 hours of settling is less than $1.5 \times 10^{5} \mathrm{dpm} / \mathrm{ml}$. The plutonium and americium concentrations in the supernate samples after 3.5 hours of settling time are less 
$1.0 \times 10^{4} \mathrm{dpm} / \mathrm{ml}$. The weight percent of suspended solids remaining in the supernate was the highest for the HAW \#3 supernate when compared with that of the HAW \#1 and HAW \#2 supernates.

\section{$\underline{\text { SEM Analysis of HAW \#3 }}$}

Results from SEM analysis of suspended solids filtered from the 3.5 and 20 hour HAW \#3 supernates are presented in Figure 8A. The major components in both suspended solid samples are sodium, aluminum, titanium, and manganese. Mercury was only identified in the 3.5 hour suspended solid sample.

Table 8. Characterization of Basic HAW \#3 Supernate and Slurry

\begin{tabular}{|c|c|c|c|}
\hline \multicolumn{4}{|c|}{ Initial Conditions: $10.3 \mathrm{wt} \%$ suspended solids in $80 \mathrm{ml} \mathrm{HAW} \mathrm{\# 3} \mathrm{solution} \mathrm{made} \mathrm{basic} \mathrm{before} \mathrm{settling.}$} \\
\hline \multicolumn{4}{|c|}{ Final Conditions: $62 \mathrm{ml}$ supernate / $6 \mathrm{ml}$ slurry after settling for 20 hours. } \\
\hline Analysis & 0 Hour Supernate & 3.5 Hour Supernate & 20+ Hour Supernate \\
\hline Mercury (ppm) & $<1.2$ & 1.5 & 2.8 \\
\hline Aluminum (\% soluble, $\mathrm{M})$ & $100,0.89 \mathrm{M}$ & $92.4,0.82 \mathrm{M}$ & $92.4,0.82 \mathrm{M}$ \\
\hline Total alpha, $(\mathrm{dpm} / \mathrm{ml})$ & $8.86 \times 10^{4}$ & $1.1 \times 10^{4}$ & $7.7 \times 10^{3}$ \\
\hline $\mathrm{Pu}$ alpha $(\mathrm{dpm} / \mathrm{ml})$ & $2.52 \times 10^{4}$ & $7.3 \times 10^{3}$ & $3.3 \times 10^{3}$ \\
\hline $\mathrm{Am}-241,(\mathrm{dpm} / \mathrm{ml})$ & $<4.2 \times 10^{3}$ & $<1.1 \times 10^{3}$ & $<1.45 \times 10^{3}$ \\
\hline Total Beta, $(\mathrm{dpm} / \mathrm{ml})$ & $1.82 \times 10^{6}$ & $1.56 \times 10^{6}$ & $1.3 \times 10^{6}$ \\
\hline Sr-90, (dpm/ml) & $1.78 \times 10^{5}$ & $1.4 \times 10^{5}$ & $3.48 \times 10^{4}$ \\
\hline \multicolumn{4}{|l|}{ Gamma Scan $(\mathrm{dpm} / \mathrm{ml})$} \\
\hline Cs-137 & $3.14 \times 10^{5}$ & $2.56 \times 10^{5}$ & $2.66 \times 10^{5}$ \\
\hline Sb-125 & $9.7 \times 10^{5}$ & $8.4 \times 10^{5}$ & $8.2 \times 10^{5}$ \\
\hline \multicolumn{4}{|l|}{ ICP-ES (ppm) } \\
\hline Total Sr (ppm) & 15.7 & 4.2 & 4.9 \\
\hline $\mathrm{Fe} / \mathrm{Mn} / \mathrm{S}(\mathrm{ppm})$ & $15 / 43 / 13$ & $7.2 / 39 / 8.7$ & $2.8 / 17 / 8.4$ \\
\hline Density $\left(\mathrm{g} / \mathrm{cm}^{3}\right)$ & NA & NA & $\begin{array}{l}1.31 \text { final supernate } \\
1.43 \text { settled slurry }\end{array}$ \\
\hline Viscosity (Centipoise) & NA & NA & $\begin{array}{c}4.5 \pm 0.9 \text { re-mixed } \\
\text { solution }\end{array}$ \\
\hline Suspended Solids (wt \%) & NA & 6.47 & 3.27 \\
\hline Slurried solids (wt \%) & NA & NA & 54.9 \\
\hline
\end{tabular}

*All supernate samples unfiltered.

Table 9. Characterization of Acidified HAW \#3 Settled Slurry

\begin{tabular}{|c|c|}
\hline \multicolumn{2}{|c|}{ Characterization of Solids in HAW \#3 Slurry } \\
\hline Run Conditions: 1-ml slurry dissolved in 50 ml of 4 $\mathrm{MNO}_{3}$ \\
\hline Analysis & 20 Hour Slurry \\
\hline Total alpha & $1.1 \times 10^{6}$ \\
\hline Pu alpha, $(\mathrm{dpm} / \mathrm{ml})$ & $1.06 \times 10^{6}$ \\
\hline Total Beta, $(\mathrm{dpm} / \mathrm{ml})$ & $8.42 \times 10^{7}$ \\
\hline $\mathrm{Sr}-90$ & $3.58 \times 10^{7}$ \\
\hline Gamma Scan $(\mathrm{dpm} / \mathrm{ml})$ & \\
\hline Am-241 & $1.13 \times 10^{5}$ \\
\hline $\mathrm{Cs}-137$ & $2.55 \times 10^{5}$ \\
\hline Sb-125 & $3.88 \times 10^{6}$ \\
\hline
\end{tabular}




\section{$\underline{\text { Settling of the HAW Solids }}$}

The settling curves are shown in Figures 1, 2, and 3 for HAW \#1, HAW \#2, and HAW \#3 solutions after being made basic with excess $\mathrm{NaOH}$. For each, the slurry height is given as a percentage of the initial total volume of the basic waste so that it can be related to tank height. This depiction also allows comparison of all four solutions tested; surrogate, HAW \#1, HAW \#2, and HAW \#3 in the same basis as shown in Figure 4. As can be seen from these figures, most of the settling occurs in the first five hours. Settling after that is much slower.



Figure 1. Settling curve for HAW \#1 solution.

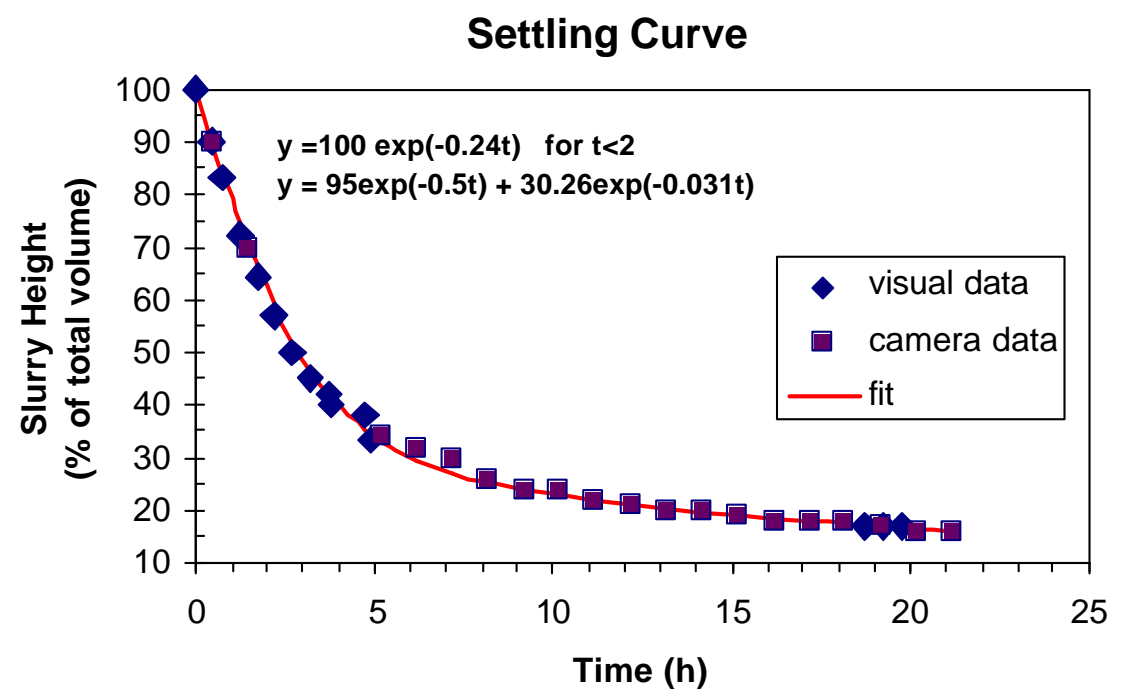

Figure 2. Settling curve for HAW \#2 solution. 
WSRC-TR-2004-00123

Revision 0

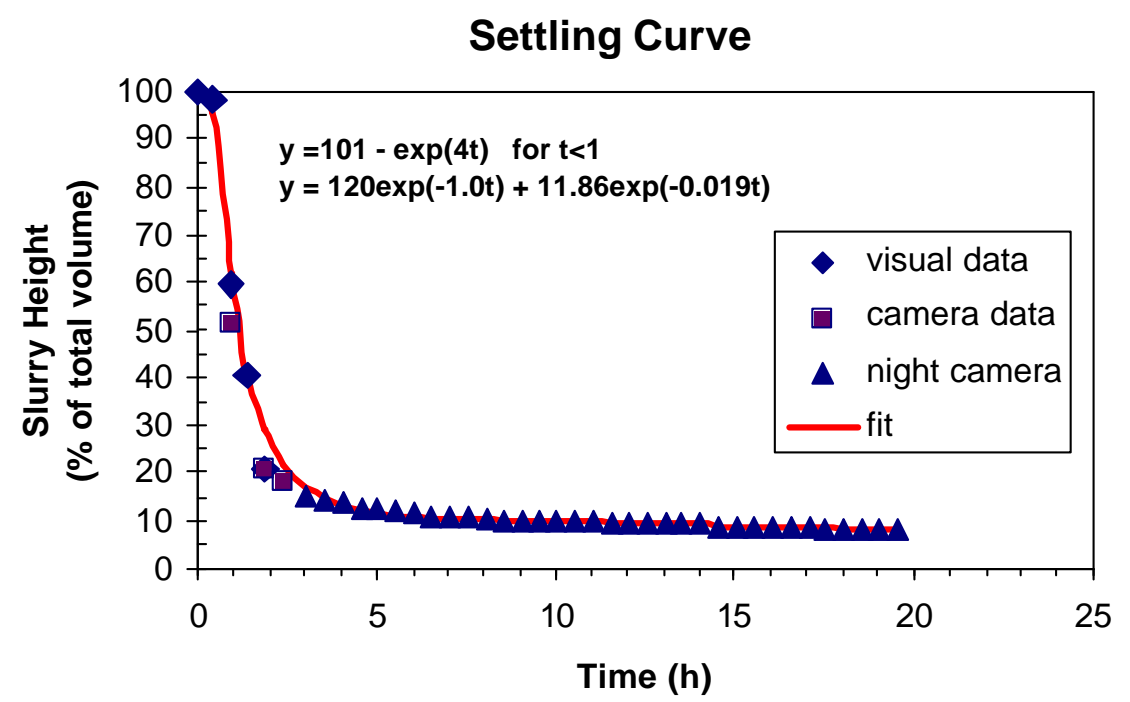

Figure 3. Settling curve for HAW \#3 solution.

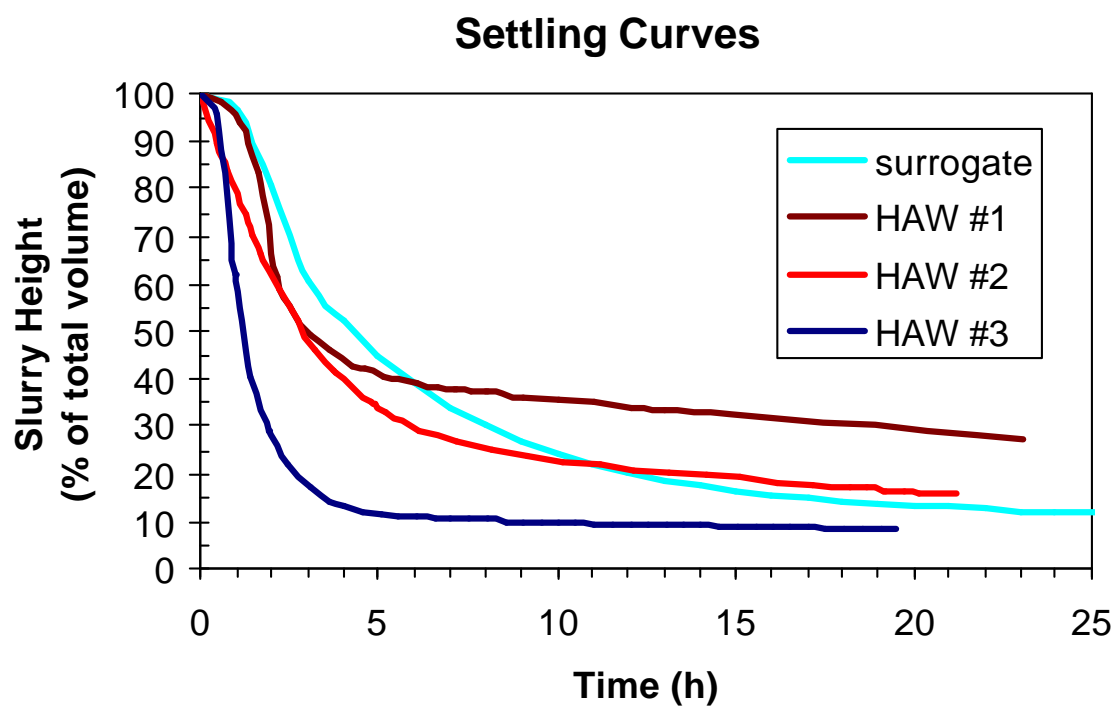

Figure 4. Settling curves for the three HAW solutions and the surrogate solution.

An attempt to fit the settling curves to expected physical processes was made to see if a predictive model would describe all of the curves. Unfortunately, the theory for sedimentation or settling is not mature. In reality settling curves are experimentally determined and fits are either by an exponential, asymptotic, or power law function. Three regions are defined for settling curves; flocculation, unhindered settling (or settling) and hindered settling or consolidation.[3,4] In the initial flocculation region, the solid particles are buoyed by the solution. After a time of agglomeration, they are heavy enough to sink without being hindered by the solids below them. Finally in the hindered region, the solid particles sink at a slower velocity due to the other solids below them. An asymptotic settling to the final height is indicative of the hindered settling region.

The settling curves obtained for the settled solids are much like the curves determined in other recent neutralization work.[8] Flocculation, as seen in the surrogate and HAW \#1 unheated slurries, fits to a y = 
$101-\exp (\mathrm{xt})$ function which shows slow initiation to settling followed by typical faster settling curve after the first 2-3 hours. Here $y$ is the percent of the total height that the slurry takes up. The curve in the following regions was fit by the sum of two exponential functions so that unhindered settling from $\sim 3-10$ hours and the hindered settling at $>10$ hours could be represented. The heated HAW \#3 settling curve is between these two cases, having a minimal flocculation region of less than an hour followed by a curve which is closer to the heated HAW \#2 solution. The HAW \#3 settling curve was thus fit with a shorter one hour versus two hour flocculation region.

Three things should be noted. The first is that the settling curve for HAW \#2 slurry, does not appear to have a flocculation region. This behavior may be due to the absence of Mn and/or the heating of the slurried solution so that the solids are larger allowing them to begin unhindered settling sooner. HAW \#2 is fit by $\mathrm{y}=100 \exp (\mathrm{xt})$. Note HAW \#3 slurry although heated has Mn and a small flocculation region. The second is that ratio of B's, the intercepts from the hindered settling, to some extent, fits the ratio of total $\mathrm{Fe}$ and $\mathrm{Mn}$ (or precipitating metals) in the solutions. The same is true of the slurry height in the hindered region. Finally, the coefficients found do not give a predictive model that can be used at different HAW solution concentrations.

Table 10. Settling Curve Fit Parameters.

\begin{tabular}{|c|c|c|c|c|c|}
\hline \multirow{3}{*}{ Settling Curve } & $\begin{array}{l}\mathrm{t}=2 \text { hours } \\
\mathrm{y}=101-\exp (\mathrm{xt}) \\
* \mathrm{y}=100 \exp (\mathrm{xt})\end{array}$ & $\begin{array}{l}\mathrm{l}>2 \text { hours } \\
\mathrm{y}=\text { Aexp(-at) }+\operatorname{Bexp}(-\mathrm{bt}) \\
(\mathrm{t}>1 \text { hour for HAW \#3) }\end{array}$ \\
\hline & $\mathrm{x}$ & A & $\mathrm{a}$ & $\mathrm{B}$ & $\mathrm{b}$ \\
\hline Surrogate & 1.5 & 86.6 & 0.2 & 13.4 & 0.0067 \\
\hline HAW \#1 & 1.8 & 115 & 0.85 & 43.54 & 0.02 \\
\hline HAW \#2 & $*-0.24$ & 95 & 0.5 & 30.26 & 0.031 \\
\hline HAW \#3 & $4.0(\mathrm{t}=1$ hour) & 120 & 1.0 & 11.86 & 0.019 \\
\hline
\end{tabular}

\section{$\underline{\text { Viscosity of Settled Solids }}$}

The viscosities for the settled solids from the HAW \#1 and HAW \#2 solutions produced from unirradiated fuel were found to be in a range in which they can be can jetted from the H-Canyon neutralization tank. The HAW \#1 solids, which contained both Mn, Fe, and no MST were found comparable to 30 wt $\% \mathrm{NaOH}$ at $26^{\circ} \mathrm{C}$. The HAW \#2 solids, which had half the amount of Fe than HAW \#1, no Mn, and were heated with MST were found to be more viscous than $30 \mathrm{wt} \% \mathrm{NaOH}$ and less vi scous than $50 \mathrm{wt} \% \mathrm{NaOH}$.

The viscosity of the basic HAW \#3 mixed slurry was also found to be within the operating range of the HCanyon neutralization tank. No measurement of the settled solid's viscosity was made because not enough solids were present to run the test. The basic HAW \#3 mixed slurry, which contained mainly Mn, and was heated with MST was found to be more viscous than $20 \mathrm{wt} \% \mathrm{NaOH}$ and less than $30 \mathrm{wt} \% \mathrm{NaOH}$. 
WSRC-TR-2004-00123

Revision 0

Table 11. Viscosity Calibration and Basic Waste Results.

\begin{tabular}{|c|c|c|c|c|c|}
\hline $\begin{array}{c}\text { Solution } \\
\text { wt \%, settled } \\
\text { solids, or slurry }\end{array}$ & $\begin{array}{c}\text { Density }{ }^{[\mathrm{I}} \\
\mathrm{g} / \mathrm{cm}^{3} @ 20^{\circ} \mathrm{C}\end{array}$ & $\begin{array}{c}\text { Efflux Time } \\
26^{\circ} \mathrm{C} \\
\text { seconds }\end{array}$ & $\begin{array}{c}\text { Viscosity } \\
20^{\circ} \mathrm{C} \\
(\mathrm{cP})\end{array}$ & $\begin{array}{c}\text { Viscosity } \\
30^{\circ} \mathrm{C} \\
(\mathrm{cP})\end{array}$ & $\begin{array}{c}\text { Measured } \\
\text { Viscosity } \\
(\mathrm{cP})\end{array}$ \\
\hline Water & 0.99821 & $9.75 \pm 0.19$ & 1.002 & $0.7997^{1}$ & 0.97 \\
\hline $1 \% \mathrm{NaNO}_{3}$ & 1.005 & $9.95 \pm 0.10$ & 1.007 & - & 1.00 \\
\hline $2 \% \mathrm{NaOH}$ & 1.0207 & $10.3 \pm 0.11$ & 1.112 & - & 1.05 \\
\hline $30 \% \mathrm{NaNO}$ & 1.2256 & $11.8 \pm 0.10$ & 1.609 & - & 1.44 \\
\hline $10 \% \mathrm{NaOH}$ & 1.1089 & $14.4 \pm 0.16$ & 1.882 & 1.43 & 1.60 \\
\hline $20 \% \mathrm{NaOH}$ & 1.2192 & $16.7 \pm 0.11$ & 4.619 & 3.17 & 2.04 \\
\hline $30 \% \mathrm{NaOH}$ & 1.3277 & $72.5 \pm 0.38$ & 13.517 & 8.47 & 9.62 \\
\hline $50 \% \mathrm{NaOH}$ & 1.52 & $314.7 \pm 7.1$ & $55^{\mathrm{a}}$ & 47.7 & 4.8 \\
\hline $\begin{array}{c}\mathrm{HAW} \# 1 \\
\text { settled solids }\end{array}$ & 1.355 & $70.3 \pm 0.88^{*}$ & - & - & 9.5 \\
\hline $\begin{array}{c}\mathrm{HAW} \# 2 \\
\text { settled solids }\end{array}$ & 1.379 & $100.2 \pm 1.5$ & - & - & $13.8^{\mathrm{b}}$ \\
\hline $\begin{array}{c}\mathrm{HAW} \# 3 \\
\text { mixed slurry }\end{array}$ & 1.315 & $33.4 \pm 0.17^{*}$ & - & - & $4.4^{\mathrm{b}}$ \\
\hline
\end{tabular}

*average of five measurements instead of four, a) various literature viscosities were found the highest being $120 \mathrm{cP}$ used $55 \mathrm{cp}$ as it fit the line best, b) taken at $24.5^{\circ} \mathrm{C}$

Calibration curves were used to determine the HAW settled solids or mixed slurry viscosity because of the efflux time range of the viscometer and the use of ambient temperature. The efflux time was determined from an average of four measurements except for the HAW \#1 settled solids and HAW \#3 mixed slurry where five measurements were averaged. The efflux time range for a \#200 Cannon-Ubbelohde viscometer to be in the recommended viscosity range of 20-100 cSt is 200-1000 seconds.[7] A \#150 viscometer has a better viscosity range, 7 to $35 \mathrm{cSt}$, for this work but the capillary pore size is smaller so the settled solids may have plugged the viscometer. Only the $50 \mathrm{wt} \% \mathrm{NaOH}$ solution was within the efflux range allowing its viscosity to be determined with minimal error. The viscosity (in $\mathrm{mPa}$ 's or $\mathrm{cP}$ ) is found by multiplying the efflux time in seconds by the constant for the viscometer tube $(0.1 \mathrm{cSt} / \mathrm{sec})$, and by the solution density. Using the measured water viscosity and water's known value at $30^{\circ} \mathrm{C}$, the measurements outside the instrument range were found to have $\sim 20 \%$ error associated with them. A calibration curve of measured viscosity versus efflux time was determined. Additional viscosity versus efflux time calibration curves were also produced from available data at $20^{\circ} \mathrm{C}$ and $30^{\circ} \mathrm{C}$ since no data were found at the $26^{\circ} \mathrm{C}$ and 24.5 ${ }^{\circ} \mathrm{C}$ temperatures that the measurements were made.

The linear fits for the three calibration curves are listed below. $\begin{array}{ll}\text { viscosity measured }(\mathrm{cP})=0.153(\mathrm{t})-0.629 & \mathrm{R}^{2}=0.9995 \\ \text { viscosity @ } 20^{\circ} \mathrm{C}(\mathrm{cP})=0.176(\mathrm{t})-0.149 & \mathrm{R}^{2}=0.9977 \\ \text { viscosity @ } 30^{\circ} \mathrm{C}(\mathrm{cP})=0.153(\mathrm{t})-0.781 & \mathrm{R}^{2}=0.9966\end{array}$

The viscosity values determined for the settled solids and mixed slurry from all three calibration curves were found to be within the $20 \%$ error of that calculated with the viscometer constant so the latter viscosity value is reported here. The viscosities of settled solids were determined to be $10 \pm 2 \mathrm{cP}$ and $14 \pm 3 \mathrm{cP}$ respectfully for the HAW \#1 and HAW \#2 settled solids. The viscosity of the basic HAW \#3 mixed slurry was $4.5 \pm 0.9 \mathrm{cP}$. 


\section{DISCUSSION}

This study was performed to verify that decanting of HAW solutions after the H-Canyon neutralization process would allow sending the supernates directly to Saltstone as a viable disposition option. To be able to transfer these supernates to Saltstone, the Saltstone WAC must be met. Three different samples of actual HAW solutions from H-Canyon were used to determine if the Saltstone WAC concentration limits for mercury, total alpha, and fission product activities would be met assuming that most of the solids would not be transferred to Saltstone along with the supernates.

Analysis of supernates after addition of $1.2 \mathrm{M}$ excess $\mathrm{NaOH}$, and settling of solids has confirmed that the combination of dilution (from addition of caustic), precipitation of solids, and addition of MST is an effective approach to meet the Saltstone WAC. Alpha activity in the HAW from H-Canyon has continued to decline from the onset of unirradiated fuel processing to the point where alpha, and specifically Pu alpha, may not require decanting to meet the Saltstone WAC. The dissolving of unirradiated fuel has decreased total alpha after the H-Canyon neutralization process by two orders of magnitude from $4 \times 10^{7} \mathrm{dpm} / \mathrm{ml}$ prior to February 2004 to $5 \times 10^{5} \mathrm{dpm} / \mathrm{ml}$ in March 2004. In these samples, alpha from Pu accounts for $\sim 50 \%$ of the total alpha. The total alpha activity dropped further with the latest change in processing, the elimination of ferrous sulphamate (FS) in the 1A bank, as of April 25, 2004. Total alpha after FS elimination appears to have come to equilibrium of about $4 \times 10^{4} \mathrm{dpm} / \mathrm{ml}$ in the June 19,2004 waste batch. The Pu alpha is now about $6 \times 10^{3} \mathrm{dpm} / \mathrm{ml}$ which is about the expected magnitude for the fuel being dissolved. Future changes in processing conditions in H-Canyon should be made with care as they could affect the behavior of the total alpha. From the recent total alpha history of the neutralization tank, it is apparent that major processing changes, tank heals, and possibly alpha leaching from tanks during storage can affect the total alpha.

Fission product activity has also declined in the HAW from H-Canyon with the dissolving of unirradiated fuel. Prominent fission products (e.g., Cs-137, Ru-106, Ce-144, Cs-134, Sb-125, etc.) have dropped one to two orders of magnitude from the start of unirradiated fuel processing in January 2004. Unlike the total alpha, no real lowering of the fission products was expected or seen in the HAW with the elimination of FS because FS mainly affects the alpha nuclides. The two fission products, Cs-137 and Sb-125, have the highest activity at approximately $1 \times 10^{6}$ and $2 \times 10^{6} \mathrm{dpm} / \mathrm{ml}$, respectively, as of May 2004. Unfortunately, these two nuclides are also expected to be in the supernate. Cesium is expected because it is very soluble in base and $\mathrm{Sb}$ is expected because it is amphoteric, forming $\mathrm{Sb}(\mathrm{OH})_{4}{ }^{-}$at high base concentrations.

The fission product activity is higher than expected for the unirradiated fuel being dissolved. One would expect that the fission product activity will drop with further dissolution and come to an equilibrium value closer to the value expected from the fuel. Evidence can be seen of the approach toward a lower fission product equilibrium value in Table 1 . The total beta and Cs-137 activities of the HAW solutions studied are becoming lower.

\section{$\underline{\text { Mercury }}$}

Initially, this study was concerned with the amount of $\mathrm{Hg}$ that would be in the supernate due to the large amount of $\mathrm{Hg}$ used to dissolve the fuel. In the waste tanks, the $\mathrm{Hg}$ is mainly found in the sludge layer as $\mathrm{HgO}$ and $\mathrm{Hg}$ but soluble species such as $\mathrm{Na}[\mathrm{HgO}(\mathrm{OH})]$ have been reported.[9] The scoping test showed only $18 \mathrm{ppm}$ of $\mathrm{Hg}$ remained in the supernate after $\mathrm{NaOH}$ addition.[2] This amount was close to a simple computer equilibrium solubility calculation of $20 \mathrm{ppm}$. The low temperature addition of base to HAW \#1 had <1.2 ppm of $\mathrm{Hg}$ in the supernate after settling. The high temperature addition of base to HAW \#2 had, after settling, considerably more $\mathrm{Hg}$ in the supernate with $87 \mathrm{ppm}$. Mercury was increasing in the HAW \#3 supernate with time, but it was closer to the HAW\# 1 supernate with $2.8 \mathrm{ppm} \mathrm{Hg}$. However, due to the lowering of the amount of $\mathrm{Hg}$ used to dissolve the fuel during this campaign, it appears that the simple volume dilution due to caustic addition will sufficiently lower the $\mathrm{Hg}$ concentration to below the WAC value of $375 \mathrm{mg} / \mathrm{l}$. 
Table 12. Final Results for all Basic Waste Compared to the Proposed WAC Limits.

\begin{tabular}{|c|c|c|c|c|}
\hline Analysis & $\begin{array}{c}\text { HAW \#1 (3/23) } \\
24 \text { Hour Supernate }\end{array}$ & $\begin{array}{c}\text { HAW \#2 (3/24) } \\
20 \text { Hour Supernate } \\
\text { [20 Hour slurry] }\end{array}$ & $\begin{array}{c}\text { HAW \#3 (5/3) } \\
20 \text { Hour Supernate } \\
{[20 \text { Hour slurry }]}\end{array}$ & $\begin{array}{c}\text { Proposed WAC }^{14} \\
\mathrm{pCi} / \mathrm{ml} \text { x } 2.22= \\
\mathrm{dpm} / \mathrm{ml}\end{array}$ \\
\hline $\begin{array}{l}\text { Mercury } \\
(\mathrm{ppm})\end{array}$ & $<1.2$ remaining & 86.8 (filtered) & 2.8 & $375 \mathrm{mg} / \mathrm{L}$ \\
\hline $\begin{array}{c}\text { Aluminum } \\
(\% \text { soluble, } \mathrm{M})\end{array}$ & $\begin{array}{l}86.1,0.78 \mathrm{M} \\
\text { (filtered) }\end{array}$ & $\begin{array}{c}98.5,1.0 \mathrm{M} \\
\text { (filtered) }\end{array}$ & $92.4,0.82 \mathrm{M}$ & $\begin{array}{c}1.41 \times 10^{5} \mathrm{mg} / \mathrm{L} \\
\text { as } \mathrm{Al} \sim 5 \mathrm{M}\end{array}$ \\
\hline $\begin{array}{l}\text { Total alpha, } \\
\text { (dpm/ml) }\end{array}$ & $<1.32 \times 10^{4}$ & $\begin{array}{c}<1.32 \times 10^{4} \\
(\text { filtered ) } \\
<1.5 \times 10^{4} \\
(\text { not filtered }) \\
{\left[1.98 \times 10^{6}\right]}\end{array}$ & $\begin{array}{l}7.7 \times 10^{3} \\
{\left[1.1 \times 10^{6}\right]}\end{array}$ & $5.55 \times 10^{4}$ \\
\hline $\begin{array}{l}\text { Pu alpha, } \\
\text { (dpm/ml) }\end{array}$ & (*) $<3.45 \times 10^{4}$ & $\begin{array}{c}4.60 \times 10^{3} \\
(\text { filtered }) \\
5.37 \times 10^{3} \\
(\text { not filtered }) \\
{\left[1.62 \times 10^{6}\right]} \\
\end{array}$ & $\begin{array}{c}3.3 \times 10^{3} \\
{\left[1.06 \times 10^{6}\right]}\end{array}$ & $\begin{array}{c}5.00 \times 10^{4} \\
\text { for }(238,239,240)\end{array}$ \\
\hline Am-241, dpm/ml & & & $\begin{array}{l}<1.45 \times 10^{3} \\
{\left[1.13 \times 10^{5}\right]}\end{array}$ & $5.00 \times 10^{4}$ \\
\hline $\begin{array}{l}\text { Total Beta, } \\
(\mathrm{dpm} / \mathrm{ml})\end{array}$ & $2.05 \times 10^{6}$ & $\begin{array}{c}1.52 \times 10^{6} \\
(\text { filtered }) \\
1.96 \times 10^{6} \\
(\text { not filtered ) } \\
{\left[3.8 \times 10^{8}\right]}\end{array}$ & $\begin{array}{l}1.3 \times 10^{6} \\
{\left[8.42 \times 10^{7}\right]}\end{array}$ & $5.21 \times 10^{7}$ \\
\hline Sr-90, (dpm/ml) & & & $\begin{array}{l}\left(1.4 \times 10^{5}\right)^{(7)} \\
3.48 \times 10^{4} \\
{\left[3.58 \times 10^{7}\right]}\end{array}$ & $1.25 \times 10^{5}$ \\
\hline \multicolumn{5}{|l|}{$\begin{array}{c}\text { Gamma Scan } \\
(\mathrm{dpm} / \mathrm{ml})\end{array}$} \\
\hline Cs-137 & $1.35 \times 10^{6}$ & $\begin{array}{c}9.9 \times 10^{5} \\
(\text { filtered ) } \\
7.47 \times 10^{5} \\
(\text { not filtered ) } \\
{\left[3.0 \times 10^{6}\right]}\end{array}$ & $\begin{array}{l}2.66 \times 10^{5} \\
{\left[3.88 \times 10^{7}\right]}\end{array}$ & $3.08 \times 10^{6}$ \\
\hline Sb-125 & $3.9 \times 10^{5}$ & $\begin{array}{c}3.2 \times 10^{5} \\
(\text { filtered }) \\
2.25 \times 10^{5} \\
(\text { not filtered }) \\
{\left[8.7 \times 10^{5}\right]} \\
\end{array}$ & $\begin{array}{r}8.2 \times 10^{5} \\
{\left[2.55 \times 10^{5}\right]} \\
\end{array}$ & $5.0 \times 10^{6}$ \\
\hline $\mathrm{Fe} / \mathrm{Mn} / \mathrm{S}(\mathrm{ppm})$ & 7.8/9.6/NA & $\begin{array}{c}1.1 /<0.2 / 1749 \\
(\text { not filtered })\end{array}$ & $\begin{array}{c}2.8 / 17 / 8.4 \\
\text { ( not filtered ) }\end{array}$ & $\begin{array}{c}6000 / 900 / 69000 \\
\left(\text { as } \mathrm{SO}_{4}{ }^{2-}\right) \mathrm{mg} / \mathrm{L}\end{array}$ \\
\hline $\begin{array}{c}\text { Suspended Solids } \\
(\text { wt } \%)\end{array}$ & 0.428 supernate & 0.532 supernate & 3.27 supernate & 5.0 \\
\hline
\end{tabular}

(*) large minimum detection limit due to neutralization with excess nitric acid after samples were taken.

(†) 3.5 hour result for comparison 


\section{$\underline{\text { Aluminum }}$}

The large solubility found for $\mathrm{Al}$ was expected since $\mathrm{Al}$ is known to dissolve to a high concentration in $\mathrm{NaOH}$ due to it being an amphoteric metal. This behavior is one of the few problems encountered in the past with the neutralization process in the Canyons. Solids or gelatinous $\mathrm{Al}(\mathrm{OH})_{3}$ have occasionally been produced and removed by increasing the $\mathrm{NaOH}$ concentration which produces the soluble $\mathrm{Al}(\mathrm{OH})_{4}$ complex.[10,11] In the more recent study 1.2 $\mathrm{M} \mathrm{NaOH}$ excess was found to dissolve all of the $\mathrm{Al}$ in a $3.2 \mathrm{M} \mathrm{HNO}_{3}, 2.4 \mathrm{M} \mathrm{Al}\left(\mathrm{NO}_{3}\right)_{3}$ solution.[11] None of the solutions tested in this study attained $100 \% \mathrm{Al}$ solubility.

The lower amount of soluble $\mathrm{Al}$ in this study, may be due to the solutions not reaching equilibrium with respect to $\mathrm{Al}$ during the experiments or the solubility limit of $\mathrm{Al}$ in the basic solution. Aluminum concentration increased as the supernate aged in both the HAW \#1 and HAW \#2 supernates but decreased from $100 \%$ in the HAW \#3 supernate. For the HAW \#2 solution which was heated when being made caustic, the amount of $\mathrm{Al}$ soluble was higher (mid to upper $90 \%$ soluble) than in the unheated HAW \#1 supernate (mid 80\% soluble). Additionally, in the HAW \#3 supernate the Al concentration decreased from $100 \%$ to $92 \%$ upon aging. Previous statements are indicative of not yet attaining equilibrium solubility. The final supernate Al solubility measured for HAW \#1, HAW \#2, and HAW \#3 of $0.78 \mathrm{M}, 1.0 \mathrm{M}$, and $0.82 \mathrm{M}$ fits the previous data for sodium aluminate $\mathrm{NaAl}(\mathrm{OH})_{4}$ in a saturated $\mathrm{NaNO}_{3}, \mathrm{NaNO}_{2}, \mathrm{Na}_{2} \mathrm{SO}_{4}$, and $\mathrm{Na}_{2} \mathrm{CO}_{3}$ waste solution.[12] Note that the HAW waste is a saturated solution since the HAW evaporator evaporates to a constant density which is on the $\mathrm{Al}-\mathrm{NO}_{3}$ solubility curve.[13] Additionally, sodium nitrite was added to the HAW prior to evaporation to reduce ammonia off gassing. Although sodium nitrite addition has been stopped once FS was eliminated from the process, one would expect the evaporated solution to still be saturated.

Predicting how much of the $\mathrm{Al}$ is soluble will be much harder as the solubility range at $1 \mathrm{M} \mathrm{NaOH}$ in a saturated system ranges from $\sim 0.6 \mathrm{M}-1.0 \mathrm{M}$ and this range increases from $\sim 0.6 \mathrm{M}$ to $\sim 3.3 \mathrm{M}$ as the $\mathrm{NaOH}$ concentration increases from 1.2 M-1.8 M. The WAC proposed Al limit for Saltstone is larger than if all the $\mathrm{Al}$ in the HAW was soluble, thus the need for precise solubility limit determination is minimal.[14] Nevertheless, the approximate amount is useful to predict the solution density and viscosity which changes with the amount of $\mathrm{Al}$ in solution as seen in this study. The basic HAW \#2 supernate had a higher Al concentration and thus a higher density and viscosity.

\section{$\underline{\text { Total Alpha }}$}

Total alpha amounts dropped about an order of magnitude to below the $5 \times 10^{4} \mathrm{dpm} / \mathrm{ml}$ total alpha WAC upon being made basic to $1.2 \mathrm{M} \mathrm{OH}^{-}$excess. The initial total alpha amounts of $\sim 2 \times 10^{6} \mathrm{dpm} / \mathrm{ml}$ in HAW \#1 and HAW \#2 solutions determined in the experiments are biased high due to beta spillover in the analytical method used. The facility tank trend data of $\sim 6 \times 10^{5} \mathrm{dpm} / \mathrm{ml}$ are closer to the real values of these solutions. The HAW \#3 solution was initially $1.5 \times 10^{5} \mathrm{dpm} / \mathrm{ml}$. Total alpha after caustic addition was at least an order of magnitude lower at $<1.32 \times 10^{4} \mathrm{dpm} / \mathrm{ml}$ for all solutions. From the tank data, $50 \%$ or more of the total alpha in the original solution was due to $\mathrm{Pu}$. The rest was due to $\mathrm{U}$, Am, and other minor alpha emitters. Uranium was initially present at $98 \mathrm{mg} / \mathrm{l}$, and $88 \mathrm{mg} / \mathrm{l}$ in HAW \#1 and HAW \#2 solutions and immediately decreased an order of magnitude after caustic addition to $8 \mathrm{mg} / \mathrm{l}$ in both supernates. The uranium concentration dropped further upon aging of the supernates. HAW \#3 solution had a lower intial $\mathrm{U}$ concentration of $12 \mathrm{mg} / \mathrm{l}$ which did not change significantly. The Am contribution was minor as it was below the WAC amount in both solutions initially at $7.5 \times 10^{3}$ and $5.5 \times 10^{3} \mathrm{dpm} / \mathrm{ml}$. Again, an approximate order of magnitude decrease with caustic addition was seen as the Am-241 activity was below the limit of detection $<1.1 \times 10^{3} \mathrm{dpm} / \mathrm{ml}$ (gamma scan) for all supernates and $<1.45 \times 10^{3} \mathrm{dpm} / \mathrm{ml}$ (Am-241 test) for HAW \#3 supernate.

As $50 \%$ of the total alpha is due to Pu, its solubility is important. The highest Pu solubility of $4.1 \mu \mathrm{g} / \mathrm{l}$ $\left(1.92 \times 10^{4} \mathrm{dpm} / \mathrm{ml}\right)$ was found for the unfiltered HAW \#2 supernate after 4 hours settling. The $0.8-1.1 \mu \mathrm{g} / \mathrm{l}$ solubilities of the other supernates may seem low but they do match some previous HAW values. Specifically, the solubilities are close to the $0.68 \pm 0.14 \mu \mathrm{g} / \mathrm{l}$ Purex-HAW waste reported by Hobbs where coprecipitation of $\mathrm{Pu}$ with $\mathrm{Fe}$ and $\mathrm{U}$ was found to be important.[15] Consequently, the concentration of $\mathrm{Pu}$ 
was found to be below the expected solubility in that study. An earlier study of the solubility of Pu in SRS waste gave a range at $1.2 \mathrm{M}$ excess $\mathrm{OH}^{-}$of $13-300 \mu \mathrm{g} / \mathrm{l}$, with most of the data in the 10-20 $\mu \mathrm{g} / \mathrm{l} \mathrm{region}$.[16] The minimum of the Pu solubility curve was shown in this earlier study to be between 1.2 and $2 \mathrm{M} \mathrm{NaOH}$ in the waste supernate. Delegard noted minimum Pu solubility at $1 \mathrm{M} \mathrm{NaOH}$ where the Pu concentration dropped from $23 \mu \mathrm{g} / \mathrm{l}$ to $2.3 \mu \mathrm{g} / \mathrm{l}$ after 100 days.[17]

The Pu solubility determined in our basic HAW supernates is also very different than that found in other $\mathrm{H}$ Area neutralized wastes. After the H-Canyon neutralization process, Purex-LAW and HM-HAW waste have been found to have $1.1 \pm 0.56 \mu \mathrm{g} / \mathrm{l}$ and $350 \pm 0.14 \mu \mathrm{g} / \mathrm{l} \mathrm{Pu}$, respectively.[15] In another study of HBLine low assay plutonium (LAP) using $\mathrm{Mn}$ as a neutron poison, the $\mathrm{Pu}$ in all the basic waste samples, except where iron was present, increased a factor of five to ten in 7 days above the 24 hour amounts of $\sim 2-7$ $\mathrm{x} 10^{4} \mathrm{dpm} / \mathrm{ml}$ and to a level above the Saltstone WAC total alpha limit.[18]

As noted above, Pu solubility in basic $\mathrm{H}$-Area waste varies considerably but some generalizations have been made about Pu solubility which may explain the differences.[17,19] The minimum Pu concentration is around 1-2 M NaOH: above this $\mathrm{NaOH}$ concentration it increases proportionate to $[\mathrm{OH}]^{2}$. Increases in $\mathrm{NaOH}, \mathrm{NaNO}_{3}$, and $\mathrm{NaNO}_{2}$ increase Pu solubility by increasing $\mathrm{OH}^{-}$activity. $\mathrm{Al}(\mathrm{OH})_{4}{ }^{-}$and $\mathrm{CO}_{3}{ }^{2-}$ both increase the Pu concentration in neutralized waste by complexation. Iron is well known for its use in scavenging Pu via carrier precipitation. Thus, the Fe in HAW solutions should scavenge Pu. Total removal of Fe from HAW solutions may increase the Pu content in the basic supernate.

\section{$\underline{\text { Total Beta-Gamma }}$}

Total beta was determined to be an order of magnitude below the Saltstone WAC of $5.1 \times 10^{7} \mathrm{dpm} / \mathrm{ml}$ in the supernates of all HAW solutions studied. The initial 1-2 x $10^{8} \mathrm{dpm} / \mathrm{ml}$ beta activity of HAW \#1 and HAW \#2 solutions was decreased by a factor of 100 after caustic addition. Total beta for the HAW \#1 and HAW $\# 2$ unfiltered supernates were essentially the same at $2.05 \times 10^{6}$ and $1.96 \times 10^{6} \mathrm{dpm} / \mathrm{ml}$, respectfully. HAW \#3 solution beta activity decreased by a factor of 20 going from $2.8 \times 10^{7}$ to $1.3 \times 10^{6} \mathrm{dpm} / \mathrm{ml}$ upon being made basic. Such decreases are expected for precipitation of fission products by metal ion hydrolysis where hydrolysis decreases the metal concentration significantly unless the metal ions are amphoteric. Amphoteric metals such as $\mathrm{Al}, \mathrm{Zn}$, and $\mathrm{Sb}$ increase in concentration as the $\mathrm{OH}^{-}$concentration increases due to further hydroxide complexation. Total beta was found to decrease slightly upon aging of the supernate and to have lower activity when filtered. Both are expected from hydrolysis precipitations where more amorphous solid material in a solution will crystallize or agglomerate and precipitate with time.

Only Cs-137 and Sb-125 were above detection limits in the gamma scans. Cesium is soluble in $\mathrm{OH}^{-}$. All three supernates, HAW \#1, HAW \#2, and HAW \#3, have Cs-137 activities that are below the proposed SaltstoneWAC limit of $3.1 \times 10^{6} \mathrm{dpm} / \mathrm{ml}$ by at least a factor of two. Antimony- 125 may adhere to solids in the solution, but upon aging or settling fall to the solids layer. Initial unfiltered samples have a slightly higher activity than the filtered experiments. Both HAW \#1 and HAW \#2 supernates have about the same Sb-125 activity, of approximately $3 \times 10^{5} \mathrm{dpm} / \mathrm{ml}$. HAW \#3 is slightly higher at $8.2 \times 10^{5} \mathrm{dpm} / \mathrm{ml}$. Again, all Sb-125 activities are below the $5.0 \times 10^{6} \mathrm{dpm} / \mathrm{ml}$ of the proposed Saltstone WAC.

\section{$\underline{\text { Solids }}$}

The precipitated solids transfer, must be minimized when decanting the supernate out of the neutralization tank because they could result in the transferred waste violating the proposed Saltstone WAC limits shown in Table 12. Total beta measured in the solids for the HAW \#2 solution after caustic addition is above the WAC by an order of magnitude at $3.8 \times 10^{8} \mathrm{dpm} / \mathrm{ml}$ and slightly greater for the solids from the HAW \#3 solution after caustic addition at $8.4 \times 10^{7} \mathrm{dpm} / \mathrm{ml}$. Sr-90 in the HAW \#3 solids, at $3.58 \times 10^{7} \mathrm{dpm} / \mathrm{ml}$, is the furthest out of specs being two orders of magnitude above the WAC limits. HAW \#3 solids also have a Cs-137 activity an order of magnitude higher than the limits. Both HAW \#1 and HAW \#2 solids contain Cs-137 below the WAC. All solids contain Sb-125 amounts that are lower than the WAC. 
The total alpha in the solids of $1-2 \times 10^{6} \mathrm{dpm} / \mathrm{ml}$ is more than an order of magnitude above the $5 \times 10^{4}$ $\mathrm{dpm} / \mathrm{ml}$ of the proposed Saltstone WAC. It is interesting to note that $80 \%$ of the total alpha in the settled solids is $\mathrm{Pu}$. Thus, if solution composition changes or process changes are made, they should be made keeping in mind what contributes to low Pu solubility.

\section{$\underline{\text { Effect of Monosodium Titanate (MST) Addition }}$}

Due to the initial high alpha results in the basic HAW \#1 supernate, MST was used after the HAW \#2 caustic addition to lower the alpha content of the supernate. An MST amount was chosen that was four times the amount to be used in future HLW supernate processes due to the shorter interaction time desired for H-Canyon processing. As alpha removal by MST is rate dependent, the increased MST concentration will make up for the faster H-Canyon process. The HAW \#2 supernate was chemically similar to the basic waste solution studied by Hobbs and Pulmano [20] where Pu was lowered from $13 \mu \mathrm{g} / \mathrm{l}$ to $6 \mu \mathrm{g} / \mathrm{l}$ after MST was used. Most of the Pu removal in that study was after 8 hours of MST contact with the solution. However, another MST study [21] at $45^{\circ} \mathrm{C}$ and $65^{\circ} \mathrm{C}$ showed that higher temperatures removed Pu better. The final Pu concentration found in the high temperature study was $2 \mu \mathrm{g} / \mathrm{L}$ when using $0.2 \mathrm{~g} / \mathrm{L}$ MST. This final $\mathrm{Pu}$ concentration was reached in less than 10 hours.

Surprisingly, no real difference in the total alpha amount was found between our heated HAW \#2 supernate with MST and the HAW \#1 supernate without MST. One possible reason for this is that MST is generally added to waste solutions after they have come to equilibrium. In the waste tanks the supernate solution has had years to equilibrate and in the previous MST experiments, at least a month is allowed for the basic surrogates to equilibrate before MST experiments were undertaken. In our experiment, the MST was added immediately after reaching $1.2 \mathrm{M} \mathrm{OH}^{-}$excess. Therefore, the solution was still equilibrating with respect to $\mathrm{AlO}_{4}{ }^{-}$, as well as metal hydrolysis products, when the MST was added. The possible interaction of MST with $\mathrm{AlO}_{4}^{-}$or the metal hydrolysis compounds may explain the ineffective alpha removal.

Due to the large amount that Sr-90 was above the proposed Saltstone WAC and the possibility of removing some of the Pu alpha, MST was again used for the HAW \#3 solution after caustic addition. The basic HAW \#3 supernate alpha and fission product results are very similar in behavior over time as those for HAW \#2 supernate. However, the Sr-90 measured in the HAW \#3 supernate results don't follow the same trend. If the ratio of total beta to Sr-90 is taken for the HAW \#3 supernate, it appears that MST is removing some of the Sr-90. As the total beta and Sr-90 samples were taken at the same time, the ratio should effectively remove the contribution of suspended solids which may be in the supernate. The ratio obtained from data in Table 8 is 10,11, and 37, respectively, for 0 hours (prior to addition of MST), 3.5hours, and 20 hours after addition of MST. Thus at 20 hours it appears that MST has removed some of the Sr-90. The ratio of total alpha to $\mathrm{Pu}$ alpha does not change much in HAW \#3 suggesting that MST is not yet removing $\mathrm{Pu}$ in the first 20 hours.

\section{CONCLUSIONS}

1) The ability to lower mercury, total alpha, and most fission product concentrations in basic supernates to levels below the Saltstone WAC has been demonstrated for the HAW \#3 solution. A combination of dilution, precipitation of solids, addition of MST, and the settling of solids for at least seven hours after the $\mathrm{NaOH}$ addition is complete appears to have reduced the remaining fission product $\mathrm{Sr}-90$ concentration in the supernate to levels below the Saltstone WAC.

2) The effectiveness of MST in removing additional $\mathrm{Sr}-90$ from the HAW \#3 supernate has not been quantified. Results from a subsequent $\mathrm{NaOH}$ addition study performed on another $\mathrm{HAW}$ solution are expected to establish the contribution made by the MST addition.

3) The ability to send the entire basic HAW slurry to Saltstone without decanting cannot be supported with results obtained from this study of HAW solutions.

4) The addition of 1.2 M excess hydroxide to HAW solutions followed by decanting the supernate to Saltstone with a minimum amount of solids appears to be a viable option. 


\section{REFERENCES}

1. F. R. Weitz to J. H. Gray, HAW Waste Decanting, March 1, 2004.

2. J. H. Gray to F. R. Weitz, HAW Surrogate Solution Test Results (U), SRT-ATS-2004-00014 (Rev. 2), April 12, 2004.

3. Chemical Engineering Fluid Mechanics, R. Darby, Chapt. 14 Fluidization and Sedimentation, pp. 393-405, Dekker NY, 1996.

4. “Assessment of Hindered Settling of Fluid Mudlike Suspensions",Yigong Li, Ashish Mehta, J. Hydralic Eng. Feb 1998 pp. 176-178.

5. Handbook of Chemistry and Physics, $79^{\text {th }}$ Ed CRC Press David R. Linde ed.

6. "Physical and Global Properties, Liquid Caustic Soda" www.solvaychemicals.com from Caustic Soda-SOLVAY Technical and Engineering Service, Bulletin No 6. 1967.

7. Instructions for the use of The Cannon-Ubbelohde Viscometer, p10.0118, Cannon Instrument Co. P.O. Box 16, State Collegd PA. 16804 @2002

8. WSRC-TR-2004-00053, Rev. 0, "Neutralization of Plutonium and Enriched Uranium Solutions Containing Gadolinium as a Neutron Poison" M. G. Bronikowski and T.S. Rudisill, Feb. 2004.

9. DPSTD-80-38-2 "Technical Data Summary for the Defense Waste Processing Facility Sludge Plant” Sept 1982. Part 2 Item 400 pg. 1 of 1 9-82 Rev. 3

10. DPSPU 77-272-14 “Problem No. St-SS-G-067, Chemistry of H-Canyon Tank 16.1”, L.W. Gray to R.W.Zeyfang, Jan. 1977.

11. SRTC-ATS-2000-00099 Rev. 0 "H-Canyon Neutralization Process Flow Sheet Study” D. Burge Jun. 202000.

12. WHC-EP-0872 "Practical Modeling of Aluminum Species in High-pH Waste”, D.A. Reynolds Oct 1995.

13. DP-1500 "Processing of Irradiated Enriched Uranium Fuels at the Savannah River Plant", M.L. Hyder, et. al, April 1979

14. WSP-SSf-2004-00015 Rev. 0, memorandum from T. E. Chandler, to : D.G. Thompson "Subject: Recommended Radiological and Chemical WAC Limits for the Processing of SMECT Solution at the Saltstone Facility" Mar. 10, 2004.

15. "Precipitation of Uranium and Plutonium from Alkaline Salt Solutions" Nucl. Tech., vol. 128, pp. 103-112, Oct 1999.

16. "Recent Results on the Solubility of Uranium and Plutonium in Savannah River Site Waste Superante” D. Hobbs and D. Karraker, Nucl. Tech. vol. 114, pp.318-324, June 1996.

17. "Solubility of PuO2.H2O in Alkaline Handford High Level Waste Solution”, C. Delegard, Radiochem.Acta 41, 11-21 (1987).

18. SRT-ATS-2000-00038 Rev. 0 "Manganous Nitrate Use in LAP Solutions" R.A. Pierce, March 8, 2000 
19. Advances in Plutonium Chemistry 1967-2000, Chapt 7.3 Plutonium in Alkaline Media pp.132144, Darlene Hoffman Ed American Nuclear Society La Grange Park Ill., 2002.

20. WSRC-TR-99-00286, "Phase IV Testing of Monosodium Titanate Adsorption with Radioactive Waste" by D.T. Hobbs and R.L. Pulmano, Sept. 3, 1999.

21. WSRC-TR-99-00134, "Final Report on Phase III Testing of Monosodium Titanate Adsorption Kinetics”, D.T. Hobbs, et al., May 28, 1999. 


\section{Appendix A.}

Figures for Solids in Basic

HAW \#1, HAW \#2, and HAW \#3

Solutions 
Figure 1A Settling of Solids in Neutralized HAW \#1 and HAW \#2 Solutions



HAW \#1 Supernate after 2.5 Hours



HAW \#2 Supernate after 1.5 Hours

Figure 2A Settling of Solids in Neutralized HAW \#1 and HAW \#2 Solutions

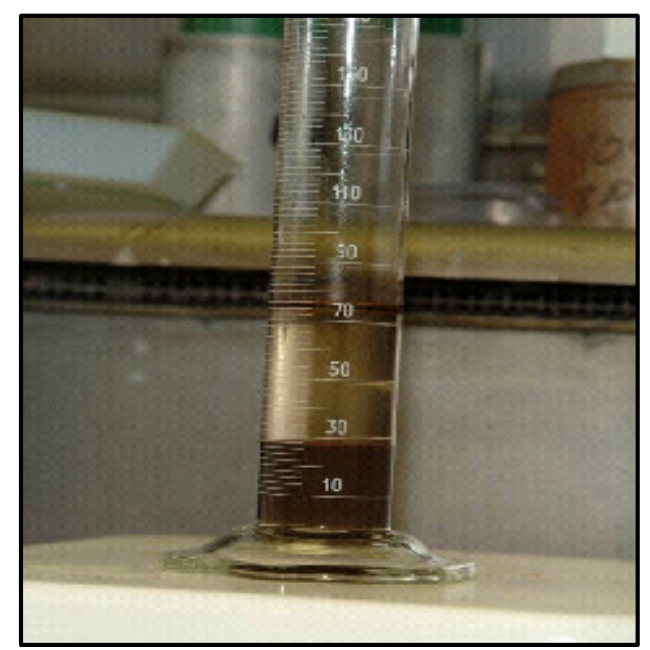

HAW \#1 Supernate after 9 Hours

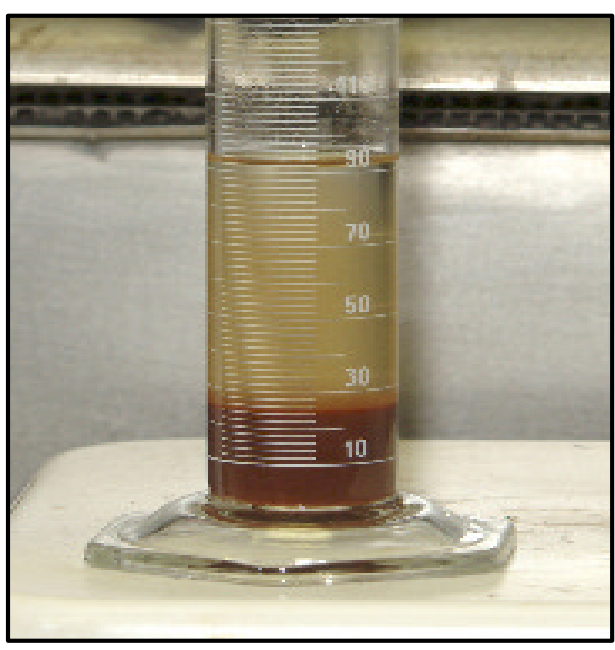

HAW \#2 Supernate after 8 Hours 
Figure 3A Settling of Solids in Neutralized HAW \#1 and HAW \#2 Solutions



HAW \#1 Supernate after 13 Hours

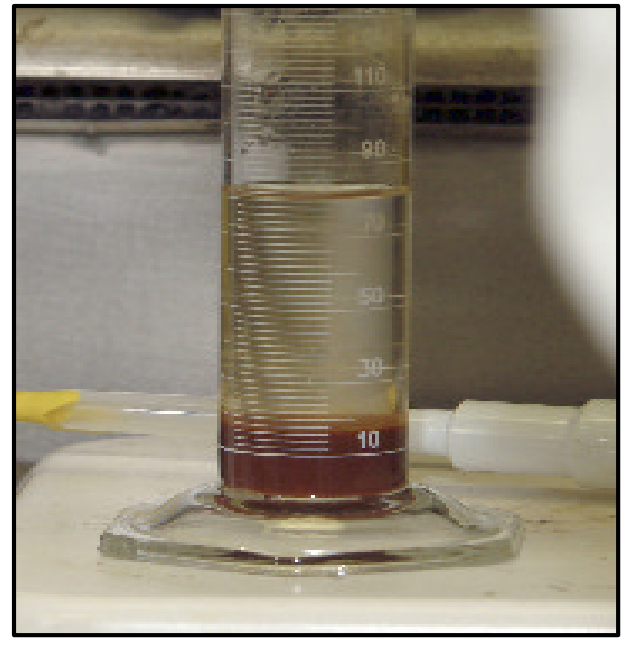

HAW \#2 in Final Supernate after 20 Hours 
Figure 4A SEM Spectra for Solids Suspended in Fully Neutralized HAW \#2 Supernate



300208226 HAW\#2Solids-1 Spot-5



HAW\#2Solids-1 5-6-04 Photo-182 Spot-3

HAW \#2 Suspended Solids after 4 Hours Settling 
Figure 5A SEM Spectra for Solids Suspended in Fully Neutralized HAW \#2 Supernate
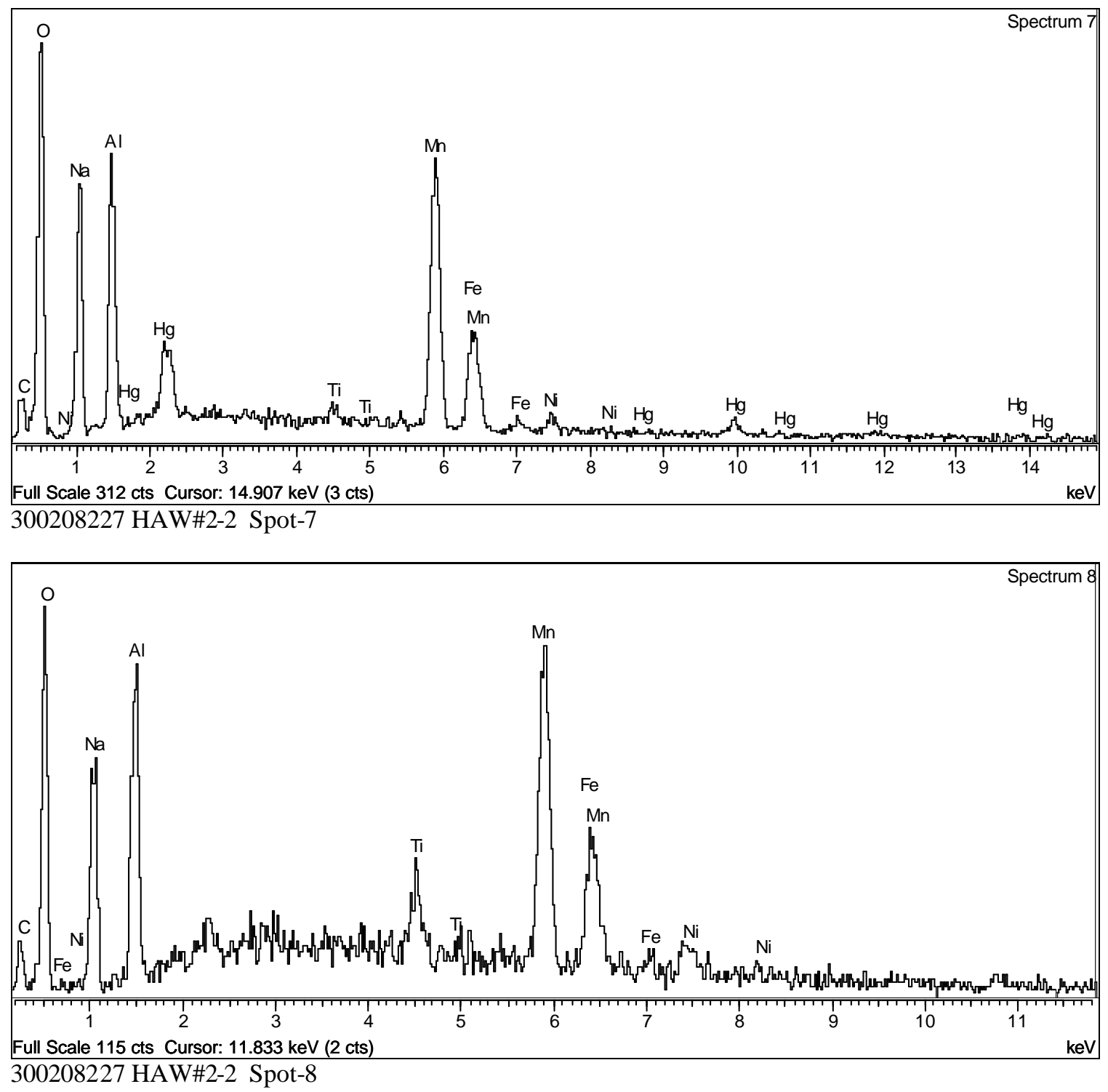

HAW \#2 Suspended Solids after 20 Hours Settling 
Figure 6A Settling of Solids in Neutralized HAW \#3 Solutions

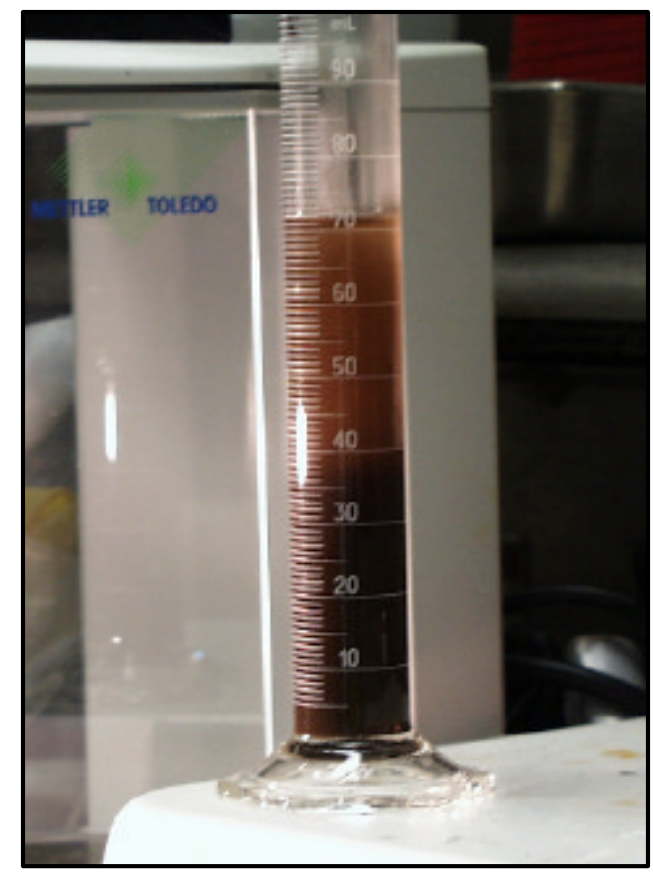

HAW \#3 Supernate after 1 Hour

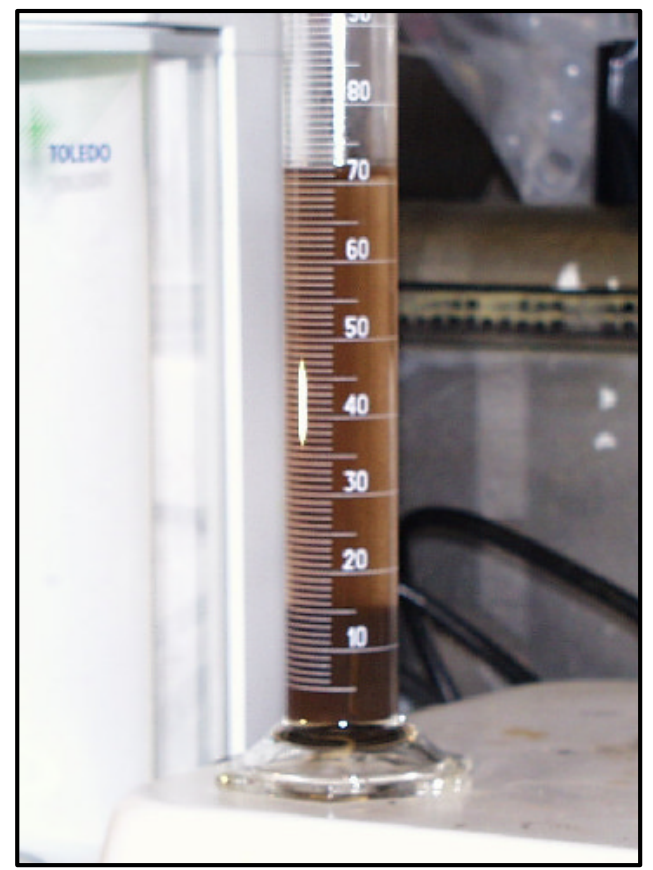

HAW \#3 Supernate after 2 Hours

Figure 7A Settling of Solids in Neutralized HAW \#3 Solutions

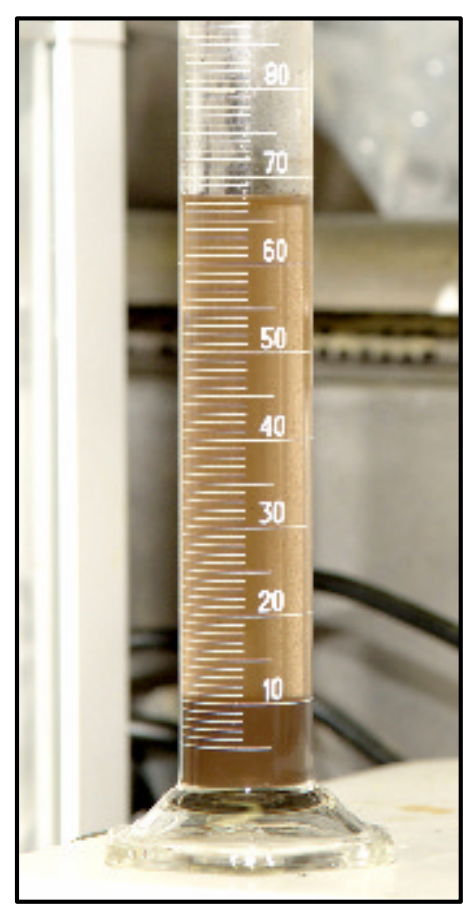

HAW \#3 Supernate after 3.5 Hour Sample Taken

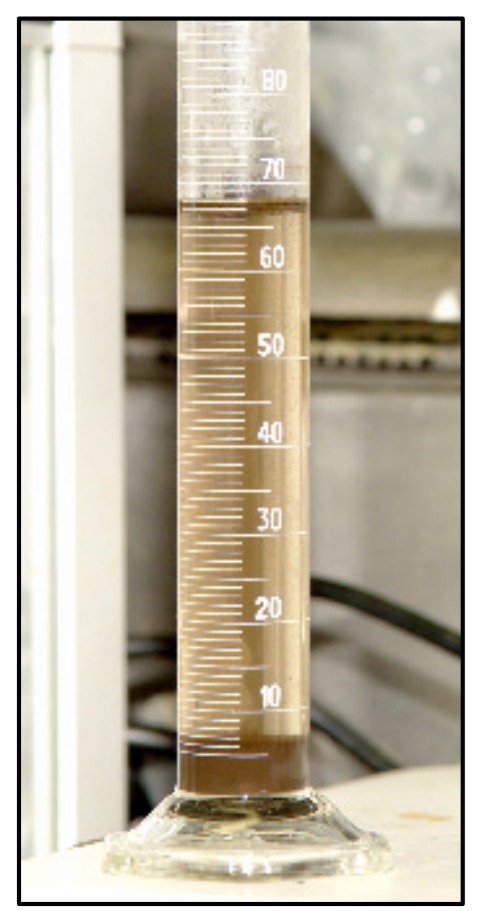

HAW \#3 Final Supernate after 20 Hours 
Figure 8A SEM Spectra for Solids Suspended in Neutralized HAW \#3 Supernates

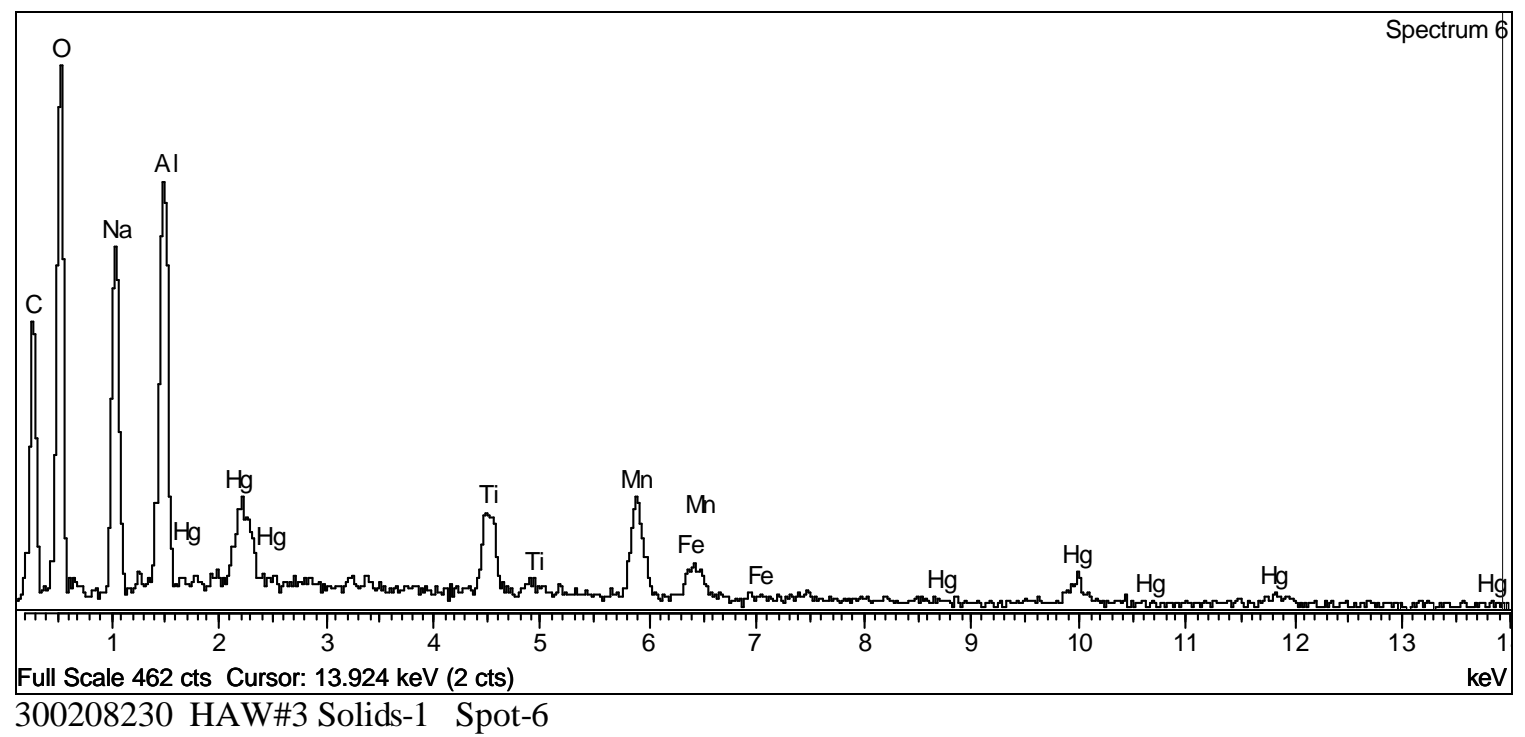

HAW \#3 Suspended Solids after 3.5 Hours Settling



HAW \#3 Suspended Solids after 20 Hours Settling 


\title{
Appendix B.
}

\author{
Compilation of Raw Data \\ Obtained from Analysis of Original and Neutralized \\ HAW \#1, HAW \#2, and HAW \#3 Solutions
}




\section{SAMPLE_ID \\ 300207459 \\ 300207459 \\ 300207459 \\ 300207459 \\ 300207459 \\ 300207459 \\ 300207460 \\ 300207459 \\ 300207458 \\ 300207457 \\ 300207459 \\ 300207459 \\ 300207460}

\section{SAMPLE ID}

300207627

300207631

300207637

300207627

300207637

300207631

300207627

300207627

300207631

300207637

300207628

300207627

300207637

300207634

300207631

300207626

300207636

300207633

300207630

300207625

300207635

USER_SAMPLEID
FILT-ORIG-4-5-6
FILT-ORIG-4-5-6
FILT-ORIG-4-5-6
FILT-ORIG-4-5-6
FILT-ORIG-4-5-6
FILT-ORIG-4-5-6
FILT-ORIG-7
FILT-ORIG-4-5-6
FILT-ORIG-3
FILT-ORIG-2
FILT-ORIG-4-5-6
FILT-ORIG-4-5-6
FILT-ORIG-7

\section{USER_SAMPLEID}

\#2-ORIG-4,5,6,8,9

3HR-FINAL-4,5,6,8,9

24HR-FINAL-4,5,6,8,9

\#2-ORIG-4,5,6,8,9

24HR-FINAL-4,5,6,8,9

3HR-FINAL-4,5,6,8,9

\#2-ORIG-4,5,6,8,9

\#2-ORIG-4,5,6,8,9

3HR-FINAL-4,5,6,8,9

24HR-FINAL-4,5,6,8,9

\#2-ORIG-7

\#2-ORIG-4,5,6,8,9

24HR-FINAL-4,5,6,8,9

7HR-FINAL-6

3HR-FINAL-4,5,6,8,9

\#2-ORIG-3

24HR-FINAL-3

7HR-FINAL-3

3HR-FINAL-3,8

\#2-ORIG-2

24HR-FINAL 2

\section{OPERATION}

GAMMA SPEC (B145)

RAD SCREEN (B145)

AM-241 (B145)

RAD SCREEN (B145)

ALPHA PHA (B145)

ALPHA PHA (B145)

FREE ACID (B154)

ALPHA COUNTING (B145)

CVAA HG (B143)

RAD ICP-ES (B147)

ALPHA PHA (B145)

ALPHA PHA (B145)

TOTAL ACID (B154)

\section{OPERATION}

GAMMA SPEC (B145)

GAMMA SPEC (B145)

GAMMA SPEC (B145)

RAD SCREEN (B145)

RAD SCREEN (B145)

RAD SCREEN (B145)

AM-241 (B145)

RAD SCREEN (B145)

RAD SCREEN (B145)

RAD SCREEN (B145)

FREE ACID (B154)

ALPHA COUNTING (B145)

ALPHA COUNTING (B145)

ALPHA COUNTING (B145)

ALPHA COUNTING (B145)

CVAA HG (B143)

CVAA HG (B143)

CVAA HG (B143)

CVAA HG (B143)

RAD ICP-ES (B147)

RAD ICP-ES (B147)

COMPONENT
\#1 original
ALPHA COUNT
AM-241
BETA COUNT
CM-244
COMMENT
FREE ACID
GROSS ALPHA COUNTS
HG
ICPES, \#1 original
PU-238/AM-241
PU-239/240
TOTAL ACID

TEXT_VALUE (x11)

UNITS

$\mathrm{pm} / \mathrm{ml}$

$\mathrm{dpm} / \mathrm{ml}$

$\mathrm{dpm} / \mathrm{mL}$

$\mathrm{dpm} / \mathrm{ml}$

$6.80 \mathrm{E}+02(2.8 \% 1 \mathrm{~S} \% \mathrm{UNC})$

$2.11 \mathrm{E}+07(15 \% 1 \mathrm{~S} \% \mathrm{UNC})$

PERCENT

RN220 $=<1 \%$, PO216 $=<1 \%$

$0.262(13)$

1.73E +05 (5\% 1S\%UNC)

$81.1(20.0)$

Attached

$96 \%$

$3 \%$

TEXT

Molar

$\mathrm{dpm} / \mathrm{mL}$

$\mathrm{mg} / \mathrm{L}$ (ppm)

$\mathrm{mg} / \mathrm{L}$ (ppm)

PERCENT

PERCENT

Molar

\section{COMPONENT TEXT_VALUE(x11)}

\#2 origional

\#13 hour

\#124 hour

ALPHA COUNT

ALPHA COUNT

ALPHA COUNT

AM-241

BETA COUNT

BETA COUNT

BETA COUNT

FREE ACID

GROSS ALPHA COUNTS

GROSS ALPHA COUNTS

GROSS ALPHA COUNTS

GROSS ALPHA COUNTS

$\mathrm{HG}$

$\mathrm{HG}$

$H G$

$\mathrm{HG}$

ICPES, \#2 origional

ICPES, \#1 24 Hour
SB-125, 1.47e5+-0.8\%, CS-137, 1.42e5+-1.3\% SB-125, 3.31e4+-1.1\%, CS -137, 1.21e5+-1.3\% SB-125, 3.57e 4+-1.0\%, CS -137, 1.25e5+-1.3\% $<8.90 \mathrm{E}+04$ (UPPER LIMIT)

$2.18 \mathrm{E}+04(35 \% 1 \mathrm{~S} \% \mathrm{UNC})$

$8.95 \mathrm{E}+04$ (25\% 1S\%UNC)

$5.00 \mathrm{E}+02(2.8 \% 1 \mathrm{~S} \% \mathrm{UNC})$

$1.13 \mathrm{E}+07(15 \% 1 \mathrm{~S} \% \mathrm{UNC})$

$2.15 \mathrm{E}+05(25 \% 1 \mathrm{~S} \% \mathrm{UNC})$

$1.86 \mathrm{E}+05(25 \% 1 \mathrm{~S} \% \mathrm{UNC})$

$0.490(+/-15 \%)$

$1.42 \mathrm{E}+05(10 \% \mathrm{UNC})$

$<8.95 \mathrm{E}+03$ (MDA)

$<4.96 \mathrm{E}+03$ (MDA)

$<1.28 \mathrm{E}+05$ (UPPER LIMIT)

$78.8(20.0)$

$<0.110(20.0)$

$<0.110(20.0)$

$<0.110(20.0)$

Attached

Attached
UNITS

$\mathrm{dpm} / \mathrm{ml}$

$\mathrm{dpm} / \mathrm{ml}$

$\mathrm{dpm} / \mathrm{ml}$

$\mathrm{dpm} / \mathrm{ml}$

$\mathrm{dpm} / \mathrm{ml}$

$\mathrm{dpm} / \mathrm{ml}$

$\mathrm{dpm} / \mathrm{mL}$

$\mathrm{dpm} / \mathrm{ml}$

$\mathrm{dpm} / \mathrm{ml}$

$\mathrm{dpm} / \mathrm{ml}$

Molar

$\mathrm{dpm} / \mathrm{mL}$

$\mathrm{dpm} / \mathrm{mL}$

$\mathrm{dpm} / \mathrm{mL}$

$\mathrm{dpm} / \mathrm{mL}$

$\mathrm{mg} / \mathrm{L}$ (ppm)

$\mathrm{mg} / \mathrm{L}(\mathrm{ppm})$

$\mathrm{mg} / \mathrm{L}$ (ppm)

$\mathrm{mg} / \mathrm{L}$ (ppm)

$\mathrm{mg} / \mathrm{L}$ (ppm)

$\mathrm{mg} / \mathrm{L}$ (ppm) 


\begin{tabular}{|c|c|}
\hline 300207632 & 7HR-FINAL-2 \\
\hline 300207629 & 3HR-FINAL-2,8 \\
\hline 300207631 & 3HR-FINAL-4,5,6,8,9 \\
\hline 300207637 & 24HR-FINAL-4,5,6,8,9 \\
\hline 300207637 & 24HR-FINAL-4,5,6,8,9 \\
\hline 300207634 & 7HR-FINAL-6 \\
\hline 300207634 & 7HR-FINAL-6 \\
\hline 300207631 & 3HR-FINAL-4,5,6,8,9 \\
\hline 300207627 & \#2-ORIG-4,5,6,8,9 \\
\hline 300207637 & 24HR-FINAL-4,5,6,8,9 \\
\hline 300207634 & 7HR-FINAL-6 \\
\hline 300207631 & 3HR-FINAL-4,5,6,8,9 \\
\hline 300207627 & \#2-ORIG-4,5,6,8,9 \\
\hline 300207631 & 3HR-FINAL-4,5,6,8,9 \\
\hline 300207634 & 7HR-FINAL-6 \\
\hline 300207637 & 24HR-FINAL-4,5,6,8,9 \\
\hline 300207631 & 3HR-FINAL-4,5,6,8,9 \\
\hline 300207634 & 7HR-FINAL-6 \\
\hline 300207631 & 3HR-FINAL-4,5,6,8,9 \\
\hline 300207634 & 7HR-FINAL-6 \\
\hline 300207637 & 24HR-FINAL-4,5,6,8,9 \\
\hline 300207637 & 24HR-FINAL-4,5,6,8,9 \\
\hline 300207628 & \#2-ORIG-7 \\
\hline SAMPLE_ID & USER_SAMPLEID \\
\hline 300208016 & 3HR-FINAL-4,5,6,8 \\
\hline 300208019 & 7HR-FINAL-6 \\
\hline 300208083 & $4 \mathrm{HR}$ - NOT FILTERED \\
\hline 300208022 & 24HR-FINAL-4,5,6,8 \\
\hline 300208084 & 7:30 - NOT FILTERED \\
\hline 300208016 & 3HR-FINAL-4,5,6,8 \\
\hline 300208022 & 24HR-FINAL-4,5,6,8 \\
\hline 300208019 & 7HR-FINAL-6 \\
\hline
\end{tabular}

$\begin{array}{ll}\text { RAD ICP-ES (B147) } & \text { ICPES, \#1 7 hour } \\ \text { RAD ICP-ES (B147) } & \text { ICPES, \#1 3 hour } \\ \text { PU TTA (B145) } & \text { PU-238 } \\ \text { PU TTA (B145) } & \text { PU-238 } \\ \text { PU TTA (B145) } & \text { PU-238 } \\ \text { PU TTA (B145) } & \text { PU-238 } \\ \text { PU TTA (B145) } & \text { PU-238 } \\ \text { PU TTA (B145) } & \text { PU-238 } \\ \text { ALPHA PHA (B145) } & \text { PU-238/AM-241 } \\ \text { ALPHA PHA (B145) } & \text { PU-238/AM-241 } \\ \text { ALPHA PHA (B145) } & \text { PU-238/AM-241 } \\ \text { ALPHA PHA (B145) } & \text { PU-238/AM-241 } \\ \text { ALPHA PHA (B145) } & \text { PU-239/240 } \\ \text { ALPHA PHA (B145) } & \text { PU-239/240 } \\ \text { ALPHA PHA (B145) } & \text { PU-239/240 } \\ \text { ALPHA PHA (B145) } & \text { PU-239/240 } \\ \text { PU TTA (B145) } & \text { PU-239/240 } \\ \text { PU TTA (B145) } & \text { PU-239/240 } \\ \text { PU TTA (B145) } & \text { PU-239/240 } \\ \text { PU TTA (B145) } & \text { PU-239/240 } \\ \text { PU TTA (B145) } & \text { PU-239/240 } \\ \text { PU TTA (B145) } & \text { PU-239/240 } \\ \text { TOTAL ACID (B154) } & \text { TOTAL ACID }\end{array}$

\section{OPERATION}

GAMMA SPEC (B145)

RAD SCREEN (B145), \#2 slurry

GAMMA SPEC (B145)

GAMMA SPEC (B145)

GAMMA SPEC (B145)

RAD SCREEN (B145)

RAD SCREEN (B145)

RAD SCREEN (B145), \#2 slurry

\section{COMPONENT}

\#2 4 hour

\#2 slurry

\#2 4 hour(unfiltered)

\#2 20 hour

\#2 20 hour (unfiltered)

ALPHA COUNT

ALPHA COUNT

ALPHA COUNT

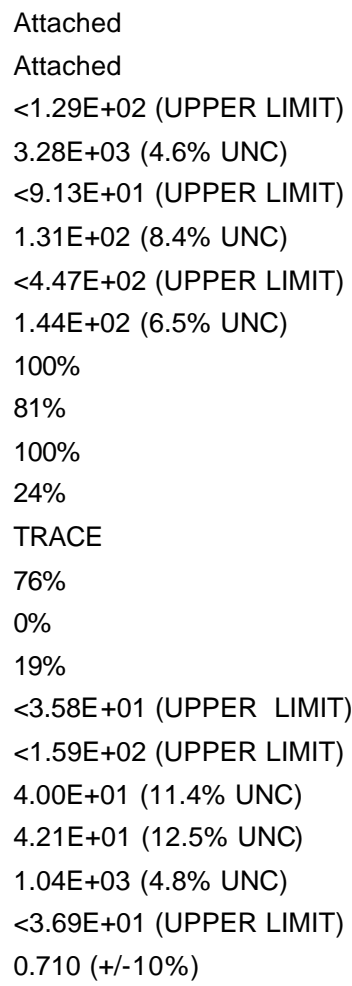

\section{UNITS}

$\mathrm{dpm} / \mathrm{ml}$ $\mathrm{dpm} / \mathrm{ml}$ $\mathrm{dpm} / \mathrm{ml}$ $\mathrm{dpm} / \mathrm{ml}$ $\mathrm{dpm} / \mathrm{ml}$ $\mathrm{dpm} / \mathrm{ml}$ $\mathrm{dpm} / \mathrm{ml}$ $\mathrm{dpm} / \mathrm{ml}$ 


$\begin{array}{ll}300208083 & 4 \text { HR - NOT FILTERED } \\ 300208084 & 7: 30 \text { - NOT FILTERED } \\ 300208016 & 3 \text { HR-FINAL-4,5,6,8 } \\ 300208022 & 24 \text { HR-FINAL-4,5,6,8 } \\ 300208083 & 4 \text { HR - NOT FILTERED } \\ 300208084 & 7: 30 \text { - NOT FILTERED } \\ 300208019 & 7 \text { HR-FINAL-6 } \\ 300208016 & 3 \text { HR-FINAL-4,5,6,8 } \\ 300208084 & 7: 30-\text { NOT FILTERED } \\ 300208083 & 4 \text { HR - NOT FILTERED } \\ 300208022 & 24 \text { HR-FINAL-4,5,6,8 } \\ 300208019 & 7 \text { HR-FINAL-6 } \\ 300208015 & 3 \text { HR-FINAL-3,8 } \\ 300208021 & 24 \text { HR-FINAL-3 } \\ 300208014 & 3 \text { HR-FINAL-2,8 } \\ 300208020 & 24 \text { HR-FINAL-2 } \\ 300208019 & 7 \text { HR-FINAL-6 } \\ 300208016 & 3 \text { HR-FINAL-4,5,6,8 } \\ 300208022 & 24 H R-F I N A L-4,5,6,8 \\ 300208084 & 7: 30-\text { NOT FILTERED } \\ 300208083 & 4 \text { HR - NOT FILTERED } \\ 300208019 & 7 \text { HR-FINAL-6 } \\ 300208016 & 3 \text { HR-FINAL-4,5,6,8 } \\ 300208022 & 24 H R-F I N A L-4,5,6,8 \\ 300208019 & 7 H R-F I N A L-6 \\ 300208084 & 7: 30-\text { NOT FILTERED } \\ 300208083 & 4 \text { HR - NOT FILTERED } \\ 300208019 & 7 H R-F I N A L-6 \\ & \end{array}$

RAD SCREEN (B145)

RAD SCREEN (B145)

RAD SCREEN (B145)

RAD SCREEN (B145)

RAD SCREEN (B145)

RAD SCREEN (B145)

RAD SCREEN (B145), \#2 slurry

ALPHA COUNTING (B145)

ALPHA COUNTING (B145)

ALPHA COUNTING (B145)

ALPHA COUNTING (B145)

ALPHA COUNTING (B145)

CVAA HG (B143)

CVAA HG (B143)

RAD ICP-ES (B147)

RAD ICP-ES (B147)

PU TTA (B145), \#2 slurry

ALPHA PHA (B145)

ALPHA PHA (B145)

ALPHA PHA (B145)

ALPHA PHA (B145)

ALPHA PHA (B145), \#2 slurry

ALPHA PHA (B145)

ALPHA PHA (B145)

ALPHA PHA (B145), \#2 slurry

ALPHA PHA (B145)

ALPHA PHA (B145)

PU TTA (B145), \#2 slurry

\begin{tabular}{ll} 
ALPHA COUNT & $<1.46 \mathrm{E}+04$ (MDA) \\
ALPHA COUNT & $<1.45 \mathrm{E}+04$ (MDA) \\
BETA COUNT & $1.42 \mathrm{E}+05(15 \%)$ \\
BETA COUNT & $1.38 \mathrm{E}+05(15 \%)$ \\
BETA COUNT & $2.67 \mathrm{E}+05(15 \%)$ \\
BETA COUNT & $1.78 \mathrm{E}+05(15 \%)$ \\
BETA COUNT & $1.15 \mathrm{E}+06(20)$ \\
GROSS ALPHA COUNTS & $<1.36 \mathrm{E}+03$ (UPPER LIMIT) \\
GROSS ALPHA COUNTS & $<1.36 \mathrm{E}+03$ (UPPER LIMIT) \\
GROSS ALPHA COUNTS & $2.59 \mathrm{E}+03(15 \%)$ \\
GROSS ALPHA COUNTS & $<1.20 \mathrm{E}+03$ (LLD) \\
GROSS ALPHA COUNTS & $6.00 \mathrm{E}+03(10)$ \\
HG & $6.62(20.0)$ \\
HG & $7.89(20.0)$ \\
ICPES, \#2 4 hour & Attched \\
ICPES, \#2 20 hour & Attched \\
PU-238 & $4.73 \mathrm{E}+03(4.4)$ \\
PU-238/AM-241 & NO IDENTIFIABLE RADIONUCLIDES > MDA \\
PU-238/AM-241 & TRACE \\
PU-238/AM-241 & $100 \%$ \\
PU-238/AM-241 & $85 \%$ \\
PU-238/AM-241 & 100 \\
PU-239/240 & NO IDENTIFIABLE RADIONUCLIDES > MDA \\
PU-239/240 & $100 \%$ \\
PU-239/240 & 0 \\
PU-239/240 & TRACE \\
PU-239/240 & $15 \%$ \\
PU-239/240 & $1.94 \mathrm{E}+02(10.3)$ \\
& \\
\hline
\end{tabular}

$\mathrm{dpm} / \mathrm{ml}$

$\mathrm{dpm} / \mathrm{ml}$

$\mathrm{dpm} / \mathrm{ml}$

$\mathrm{dpm} / \mathrm{ml}$

$\mathrm{dpm} / \mathrm{ml}$

$\mathrm{dpm} / \mathrm{ml}$

$\mathrm{dpm} / \mathrm{ml}$

$\mathrm{dpm} / \mathrm{mL}$

$\mathrm{dpm} / \mathrm{mL}$

$\mathrm{dpm} / \mathrm{mL}$

$\mathrm{dpm} / \mathrm{mL}$

$\mathrm{dpm} / \mathrm{mL}$

$\mathrm{mg} / \mathrm{L}$ (ppm)

$\mathrm{mg} / \mathrm{L}$ (ppm)

$\mathrm{mg} / \mathrm{L}$ (ppm)

$\mathrm{mg} / \mathrm{L}$ (ppm)

$\mathrm{dpm} / \mathrm{mL}$

PERCENT

PERCENT

PERCENT

PERCENT

PERCENT

PERCENT

PERCENT

PERCENT

PERCENT

PERCENT

$\mathrm{dpm} / \mathrm{mL}$ 


$\begin{array}{ll}\text { SAMPLE_ID } & \text { USER_SAMPLEID } \\ 300208454 & \text { \#3-ORIG-4,5,6,8,9,10 } \\ 300208458 & \text { 0-HR-FINAL-4,5,6,8,9,10 } \\ 300208461 & \text { 4-HR-FINAL-4,5,6,8,9,10 } \\ 300208464 & \text { 20+HR-FINAL-4,5,6,8,9,10 } \\ 300209233 & \text { 1ML-SLURRY-4,5,6,8,9,10 } \\ 300208454 & \text { \#3-ORIG-4,5,6,8,9,10 } \\ 300208458 & \text { 0-HR-FINAL-4,5,6,8,9,10 } \\ 300208461 & \text { 4-HR-FINAL-4,5,6,8,9,10 } \\ 300209233 & \text { 1ML-SLURRY-4,5,6,8,9,10 } \\ 300208464 & \text { 20+HR-FINAL-4,5,6,8,9,10 } \\ 300208454 & \text { \#3-ORIG-4,5,6,8,9,10 } \\ 300208458 & \text { 0-HR-FINAL-4,5,6,8,9,10 } \\ 300209233 & \text { 1ML-SLURRY-4,5,6,8,9,10 } \\ 300208464 & \text { 20+HR-FINAL-4,5,6,8,9,10 } \\ 300208461 & \text { 4-HR-FINAL-4,5,6,8,9,10 } \\ 300208454 & \text { \#3-ORIG-4,5,6,8,9,10 } \\ 300208458 & \text { 0-HR-FINAL-4,5,6,8,9,10 } \\ 300209233 & \text { 1ML-SLURRY-4,5,6,8,9,10 } \\ 300208464 & \text { 20+HR-FINAL-4,5,6,8,9,10 } \\ 300208461 & \text { 4-HR-FINAL-4,5,6,8,9,10 } \\ 300208454 & \text { \#3-ORIG-4,5,6,8,9,10 } \\ 300209233 & \text { 1ML-SLURRY-4,5,6,8,9,10 } \\ 300208454 & \text { \#3-ORIG-4,5,6,8,9,10 } \\ 300209233 & \text { 1ML-SLURRY-4,5,6,8,9,10 } \\ 300208458 & \text { 0-HR-FINAL-4,5,6,8,9,10 } \\ 300208464 & \text { 20+HR-FINAL-4,5,6,8,9,10 } \\ 300208455 & \text { \#3-ORIG-7,8 } \\ 300208455 & \text { \#3-ORIG-7,8 } \\ 300208454 & \text { \#3-ORIG-4,5,6,8,9,10 } \\ 300208455 & \text { \#3-ORIG-7,8 } \\ 300208454 & \text { \#3-ORIG-4,5,6,8,9,10 } \\ 300208458 & \text { 0-HR-FINAL-4,5,6,8,9,10 } \\ 300208461 & \text { 4-HR-FINAL-4,5,6,8,9,10 } \\ & \end{array}$

\section{OPERATION}

GAMMA SPEC (B145)

GAMMA SPEC (B145)

GAMMA SPEC (B145)

GAMMA SPEC (B145)

GAMMA SPEC (B145)

RAD SCREEN (B145)

RAD SCREEN (B145)

RAD SCREEN (B145)

RAD SCREEN (B145)

RAD SCREEN (B145)

AM-241 (B145)

AM-241 (B145)

AM-241 (B145)

AM-241 (B145)

AM-241 (B145)

RAD SCREEN (B145)

RAD SCREEN (B145)

RAD SCREEN (B145)

RAD SCREEN (B145)

RAD SCREEN (B145)

ALPHA PHA (B145)

ALPHA PHA (B145)

ALPHA PHA (B145)

ALPHA PHA (B145)

ALPHA PHA (B145)

ALPHA PHA (B145)

FREE ACID (B154)

TOTAL ACID (B154)

ALPHA PHA (B145)

FREE ACID (B154)

ALPHA COUNTING (B145)

ALPHA COUNTING (B145) ALPHA COUNTING (B145)

\section{COMPONENT}

\#3 original

\#3 0 hour

\#3 3.5 hour

\#3 20 hour

\#3 $1 \mathrm{ml}$ slurry

ALPHA COUNT

ALPHA COUNT

ALPHA COUNT

ALPHA COUNT

ALPHA COUNT

AM-241

AM-241

AM-241

AM-241

AM-241

BETA COUNT

BETA COUNT

BETA COUNT

BETA COUNT

BETA COUNT

CM-244

CM-244

COMMENT

COMMENT

COMMENT

COMMENT

COMMENT

COMMENT

COMMENT2

FREE ACID

GROSS ALPHA COUNTS

GROSS ALPHA COUNTS

GROSS ALPHA COUNTS
TEXT_VALUE( $x$ 11)

UNITS

$\mathrm{Sb} / \mathrm{Cs} 1.4 \mathrm{E}+05 / 3.4 \mathrm{E}+04$

$\mathrm{Sb} / \mathrm{Cs} 9.7 \mathrm{E}+05 / 3.14 \mathrm{E}+05(\times 55) \quad \mathrm{dpm} / \mathrm{ml}$

$\mathrm{Sb} / \mathrm{Cs} 8.4 \mathrm{E}+05 / 2.56 \mathrm{E}+05$

$\mathrm{Sb} / \mathrm{Cs} 8.2 \mathrm{E}+05 / 2.6 \mathrm{E}+05$

$\mathrm{Sb} / \mathrm{Cs} 3.9 \mathrm{E}+06 / 2.55 \mathrm{E}+05$

$<9.87 \mathrm{E}+04$ (MDA)

$<4.15 \mathrm{E}+01$ (MDA) (x55)

$<6.84 \mathrm{E}+02$ (UPPER LIMIT)

$<2.32$ E+03 (UPPER LIMIT)

$<7.29 \mathrm{E}+02$ (UPPER LIMT)

$1.12 \mathrm{E}+03(2.8)$

$<7.61 \mathrm{E}+01$ (MDA) (x55)

$2.06 \mathrm{E}+02$ (30)

$<1.32 \mathrm{E}+02$ (MDA)

$<9.72 \mathrm{E}+01$ (MDA)

$2.55 \mathrm{E}+06(25)$

$3.31 \mathrm{E}+04(20)(\times 55)$

$1.53 \mathrm{E}+05(10)$

$1.20 \mathrm{E}+05(30)$

$1.42 \mathrm{E}+05(20)$

$\mathrm{dpm} / \mathrm{ml}$

$\mathrm{dpm} / \mathrm{ml}$

$\mathrm{dpm} / \mathrm{ml}$

$\mathrm{dpm} / \mathrm{ml}$

$\mathrm{dpm} / \mathrm{ml}$

$\mathrm{dpm} / \mathrm{ml}$

$\mathrm{dpm} / \mathrm{ml}$

$\mathrm{dpm} / \mathrm{ml}$

$\mathrm{dpm} / \mathrm{mL}$

$\mathrm{dpm} / \mathrm{mL}$

$\mathrm{dpm} / \mathrm{mL}$

$\mathrm{dpm} / \mathrm{mL}$

$\mathrm{dpm} / \mathrm{mL}$

$\mathrm{dpm} / \mathrm{ml}$

$\mathrm{dpm} / \mathrm{ml}$

$\mathrm{dpm} / \mathrm{ml}$

$\mathrm{dpm} / \mathrm{ml}$

$\mathrm{dpm} / \mathrm{ml}$

PERCENT

PERCENT

PERCENT

$\mathrm{RN}-220=1 \%$

$\begin{array}{ll}\text { CM- } 242=1 \% \text { RN-220 }=1 \% \& \text { PO- } 216=1 \% & \text { PERCENT } \\ \text { NO IDENTIFIABLE NUCLIDES }>\text { MDA } & \text { PERCENT }\end{array}$

NO IDENTIFIABLE NUCLIDES > BKGD PERCENT

NONE

NONE

PO- $216=1 \%$

0.251

$1.37 \mathrm{E}+04(16)$

$1.61 \mathrm{E}+02(50)(\times 55)$

$1.01 \mathrm{E}+03(20)$
PERCENT

PERCENT

PERCENT

Molar

$\mathrm{dpm} / \mathrm{mL}$

$\mathrm{dpm} / \mathrm{mL}$

$\mathrm{dpm} / \mathrm{mL}$ 


$\begin{array}{ll}300209233 & \text { 1ML-SLURRY-4,5,6,8,9,10 } \\ 300208464 & \text { 20+HR-FINAL-4,5,6,8,9,10 } \\ 300208453 & \text { \#3-ORIG-3,8 } \\ 300208457 & \text { 0-HR-FINAL-3,8 } \\ 300208463 & \text { 20+HR-FINAL-3,8 } \\ 300208460 & \text { 4-HR-FINAL-3,8 } \\ 300208452 & \text { \#3-ORIG-2,8 } \\ 300208462 & \text { 20+HR-FINAL-2,8 } \\ 300208459 & \text { 4-HR-FINAL-2,8 } \\ 300208456 & \text { 0-HR-FINAL-2,8 } \\ 300208454 & \text { \#3-ORIG-4,5,6,8,9,10 } \\ 300208464 & \text { 20+HR-FINAL-4,5,6,8,9,10 } \\ 300209233 & \text { 1ML-SLURRY-4,5,6,8,9,10 } \\ 300208461 & \text { 4-HR-FINAL-4,5,6,8,9,10 } \\ 300208458 & \text { 0-HR-FINAL-4,5,6,8,9,10 } \\ 300208454 & \text { \#3-ORIG-4,5,6,8,9,10 } \\ 300208461 & \text { 4-HR-FINAL-4,5,6,8,9,10 } \\ 300209233 & \text { 1ML-SLURRY-4,5,6,8,9,10 } \\ 300208454 & \text { \#3-ORIG-4,5,6,8,9,10 } \\ 300209233 & \text { 1ML-SLURRY-4,5,6,8,9,10 } \\ 300208461 & \text { 4-HR-FINAL-4,5,6,8,9,10 } \\ 300208454 & \text { \#3-ORIG-4,5,6,8,9,10 } \\ 300208458 & \text { 0-HR-FINAL-4,5,6,8,9,10 } \\ 300208461 & \text { 4-HR-FINAL-4,5,6,8,9,10 } \\ 300208464 & \text { 20+HR-FINAL-4,5,6,8,9,10 } \\ 300209233 & \text { 1ML-SLURRY-4,5,6,8,9,10 } \\ 300208458 & \text { 0-HR-FINAL-4,5,6,8,9,10 } \\ 300208461 & \text { 4-HR-FINAL-4,5,6,8,9,10 } \\ 300208464 & \text { 20+HR-FINAL-4,5,6,8,9,10 } \\ 300209233 & \text { 1ML-SLURRY-4,5,6,8,9,10 } \\ 300208455 & \text { \#3-ORIG-7,8 } \\ 300\end{array}$

$\begin{array}{ll}\text { ALPHA COUNTING (B145) } & \text { GROSS ALPHA COUNTS } \\ \text { ALPHA COUNTING (B145) } & \text { GROSS ALPHA COUNTS } \\ \text { CVAA HG (B143) } & \text { HG } \\ \text { CVAA HG (B143) } & \text { HG } \\ \text { CVAA HG (B143) } & \text { HG } \\ \text { CVAA HG (B143) } & \text { HG } \\ \text { RAD ICP-ES (B147) } & \text { ICPES } \\ \text { RAD ICP-ES (B147) } & \text { ICPES } \\ \text { RAD ICP-ES (B147) } & \text { ICPES } \\ \text { RAD ICP-ES (B147) } & \text { ICPES } \\ \text { PU TTA (B145) } & \text { PU-238 } \\ \text { PU TTA (B145) } & \text { PU-238 } \\ \text { PU TTA (B145) } & \text { PU-238 } \\ \text { PU TTA (B145) } & \text { PU-238 } \\ \text { PU TTA (B145) } & \text { PU-238 } \\ \text { ALPHA PHA (B145) } & \text { PU-238/AM-241 } \\ \text { ALPHA PHA (B145) } & \text { PU-238/AM-241 } \\ \text { ALPHA PHA (B145) } & \text { PU-238/AM-241 } \\ \text { ALPHA PHA (B145) } & \text { PU-239/240 } \\ \text { ALPHA PHA (B145) } & \text { PU-239/240 } \\ \text { ALPHA PHA (B145) } & \text { PU-239/240 } \\ \text { PU TTA (B145) } & \text { PU-239/240 } \\ \text { PU TTA (B145) } & \text { PU-239/240 } \\ \text { PU TTA (B145) } & \text { PU-239/240 } \\ \text { PU TTA (B145) } & \text { PU-239/240 } \\ \text { PU TTA (B145) } & \text { PU-239/240 } \\ \text { SR90 BETA LIQ SCINT (B145) } & \text { SR-90 } \\ \text { SR90 BETA LIQ SCINT (B145) } & \text { SR-90 } \\ \text { SR90 BETA LIQ SCINT (B145) } & \text { SR-90 } \\ \text { SR90 BETA LIQ SCINT (B145) } & \text { SR-90 } \\ \text { TOTAL ACID (B154) } & \text { TOTAL ACID } \\ & \\ \text { PLH } & \end{array}$

$2.02 \mathrm{E}+03(12)$
$6.89 \mathrm{E}+01(50)$
$64.9(20.0)$
$<0.110(20.0)(x 55)$
$0.256(20.0)$
$1.33(20.0)$
ATTACHED
ATTACHED
ATTACHED
ATTACHED (x55)
$1.03 \mathrm{E}+04(4.1)$
$3.77 \mathrm{E}+02(20.0)$
$1.83 \mathrm{E}+03(4.5)$
$5.18 \mathrm{E}+02(20.0)$
$3.09 \mathrm{E}+02(20.0)(x 55)$
95
87
91
0
6
13
$2.77 \mathrm{E}+02(9.0)$
$1.49 \mathrm{E}+02(20.0)(x 55)$
$1.48 \mathrm{E}+02(20.0)$
$1.65 \mathrm{E}+02(20.0)$
$8.92 \mathrm{E}+01(8.9)$
$3.23 \mathrm{E}+03(11.3)(x 55)$
$1.27 \mathrm{E}+04(8.6)$
$3.16 \mathrm{E}+03(12.0)$
$6.50 \mathrm{E}+04(8.3)$
0.427

\author{
$\mathrm{dpm} / \mathrm{mL}$ \\ $\mathrm{dpm} / \mathrm{mL}$ \\ $\mathrm{mg} / \mathrm{L}$ (ppm) \\ $\mathrm{mg} / \mathrm{L}$ (ppm) \\ $\mathrm{mg} / \mathrm{L}$ (ppm) \\ $\mathrm{mg} / \mathrm{L}$ (ppm) \\ $\mathrm{mg} / \mathrm{L}$ (ppm) \\ $\mathrm{mg} / \mathrm{L}$ (ppm) \\ $\mathrm{mg} / \mathrm{L}$ (ppm) \\ $\mathrm{mg} / \mathrm{L}$ (ppm) \\ $\mathrm{dpm} / \mathrm{mL}$ \\ $\mathrm{dpm} / \mathrm{mL}$ \\ $\mathrm{dpm} / \mathrm{mL}$ \\ $\mathrm{dpm} / \mathrm{mL}$ \\ $\mathrm{dpm} / \mathrm{mL}$ \\ PERCENT \\ PERCENT \\ PERCENT \\ PERCENT \\ PERCENT \\ PERCENT \\ $\mathrm{dpm} / \mathrm{mL}$ \\ $\mathrm{dpm} / \mathrm{mL}$ \\ $\mathrm{dpm} / \mathrm{mL}$ \\ $\mathrm{dpm} / \mathrm{mL}$ \\ $\mathrm{dpm} / \mathrm{mL}$ \\ $\mathrm{dpm} / \mathrm{mL}$ \\ $\mathrm{dpm} / \mathrm{mL}$ \\ $\mathrm{dpm} / \mathrm{mL}$ \\ $\mathrm{dpm} / \mathrm{mL}$ \\ Molar
}


WSRC-TR-2004-00123

Revision 0

ICPES Results from B-

$147 \mathrm{JY} 170 \mathrm{C}$

Analytical Development Section, SRTC, 5-5523

Calculated: $\quad$ 5/14/04

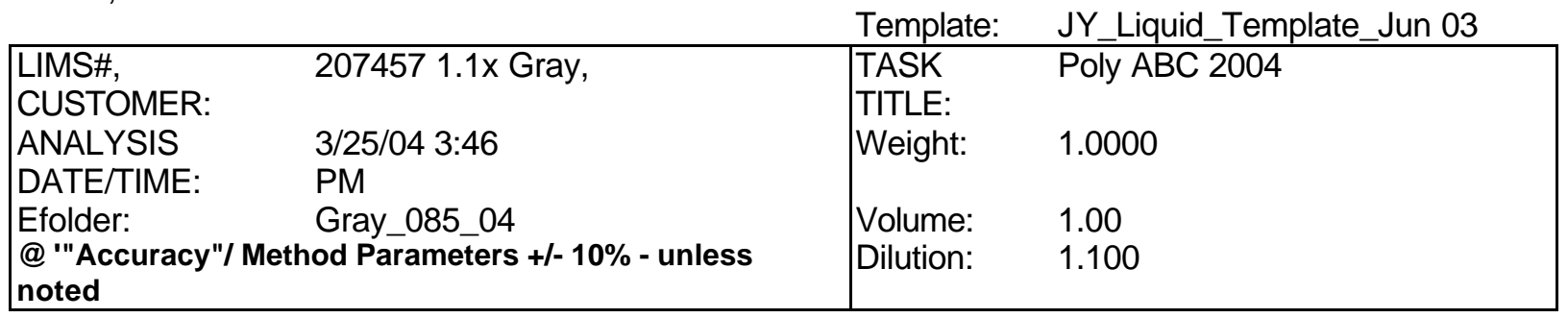

\begin{tabular}{|c|c|c|}
\hline \multicolumn{3}{|c|}{ HAW \#1 Original (x 11) } \\
\hline Analyte & Result (x11) & $\begin{array}{c}\text { \#"Precision" } \\
\text { \%RSD }\end{array}$ \\
\hline $\mathrm{Ag}$ & $0.068 \mathrm{mg} / \mathrm{L}$ & 5 \\
\hline $\mathrm{Al}$ & $2810 \mathrm{mg} / \mathrm{L}$ & 5 \\
\hline $\mathrm{B}$ & $3.13 \mathrm{mg} / \mathrm{L}$ & 18 \\
\hline $\mathrm{Ba}$ & $2.14 \mathrm{mg} / \mathrm{L}$ & 5 \\
\hline $\mathrm{Ca}$ & $1.15 \mathrm{mg} / \mathrm{L}$ & 5 \\
\hline $\mathrm{Cd}$ & $0.141 \mathrm{mg} / \mathrm{L}$ & 85 \\
\hline $\mathrm{Ce}$ & $0.328 \mathrm{mg} / \mathrm{L}$ & 6 \\
\hline $\mathrm{Cr}$ & $7.27 \mathrm{mg} / \mathrm{L}$ & 6 \\
\hline $\mathrm{Cu}$ & $2.11 \mathrm{mg} / \mathrm{L}$ & 5 \\
\hline $\mathrm{Fe}$ & $193 \mathrm{mg} / \mathrm{L}$ & 5 \\
\hline $\mathrm{Gd}$ & $0.131 \mathrm{mg} / \mathrm{L}$ & 5 \\
\hline $\mathrm{K}$ & $<8.23 \mathrm{mg} / \mathrm{L}$ & N/A \\
\hline $\mathrm{La}$ & $0.079 \mathrm{mg} / \mathrm{L}$ & 5 \\
\hline $\mathrm{Li}$ & $<0.043 \mathrm{mg} / \mathrm{L}$ & N/A \\
\hline $\mathrm{Mg}$ & $13.6 \mathrm{mg} / \mathrm{L}$ & 5 \\
\hline$\overline{\mathrm{Mn}}$ & $200 \mathrm{mg} / \mathrm{L}$ & 5 \\
\hline Mo & $7.06 \mathrm{mg} / \mathrm{L}$ & 5 \\
\hline $\mathrm{Na}$ & $569 \mathrm{mg} / \mathrm{L}$ & 5 \\
\hline $\mathrm{Ni}$ & $20.4 \mathrm{mg} / \mathrm{L}$ & 5 \\
\hline $\mathrm{P}$ & $4.06 \mathrm{mg} / \mathrm{L}$ & 57 \\
\hline $\mathrm{Pb}$ & $<0.369 \mathrm{mg} / \mathrm{L}$ & N/A \\
\hline $\bar{S}$ & $230 \mathrm{mg} / \mathrm{L}$ & 5 \\
\hline $\mathrm{Sb}$ & $7.63 \mathrm{mg} / \mathrm{L}$ & 5 \\
\hline $\mathrm{Sn}$ & $3.46 \mathrm{mg} / \mathrm{L}$ & 10 \\
\hline $\mathrm{Sr}$ & $0.510 \mathrm{mg} / \mathrm{L}$ & 5 \\
\hline $\mathrm{Ti}$ & $0.433 \mathrm{mg} / \mathrm{L}$ & 5 \\
\hline $\mathrm{U}$ & $8.40 \mathrm{mg} / \mathrm{L}$ & 5 \\
\hline $\mathrm{V}$ & $1.03 \mathrm{mg} / \mathrm{L}$ & 5 \\
\hline $\mathrm{Zn}$ & $8.58 \mathrm{mg} / \mathrm{L}$ & 5 \\
\hline $\mathrm{Zr}$ & $1.14 \mathrm{mg} / \mathrm{L}$ & 55 \\
\hline
\end{tabular}


WSRC-TR-2004-00123

Revision 0

ICPES Results from B-

147 JY170C

Analytical Development Section,

Calculated:

$5 / 17 / 04$

SRTC, 5-5523

\begin{tabular}{|c|c|c|c|}
\hline & & Template: & JY_Liquid_Template_Jun 03 \\
\hline $\begin{array}{l}\text { LIMS\#, } \\
\text { CUSTOMER: }\end{array}$ & $\begin{array}{l}2076251.1 x \text { Gray, } 20766291.1 x \\
\text { Gray }\end{array}$ & $\begin{array}{l}\text { TASK } \\
\text { TITLE: }\end{array}$ & Poly ABC 2004 \\
\hline ANALYSIS & 4/6/04 3:46 PM & Weight: & 1.0000 \\
\hline Efolder: & $\begin{array}{l}\text { Gray_097_098_ } \\
04\end{array}$ & Volume: & 1.00 \\
\hline $\begin{array}{l}\text { @ "'Accuracy"' } \\
\text { noted }\end{array}$ & nod Parameters +/- 10\% - unless & Dilution: & 4.000 \\
\hline
\end{tabular}

\begin{tabular}{|c|c|c|c|c|c|}
\hline \multicolumn{3}{|c|}{ HAW \#2 Original } & \multicolumn{3}{|c|}{ HAW \#1 3 Hour } \\
\hline Analyte & Result (x11) & $\begin{array}{c}\text { \#"Precision" } \\
\text { \%RSD }\end{array}$ & Analyte & Result (x11) & $\begin{array}{c}\text { \#"Precision" } \\
\text { \%RSD }\end{array}$ \\
\hline $\mathrm{Ag}$ & $0.020 \mathrm{mg} / \mathrm{L}$ & 5 & $\mathrm{Ag}$ & $0.028 \mathrm{mg} / \mathrm{L}$ & 15 \\
\hline $\mathrm{Al}$ & $3630 \mathrm{mg} / \mathrm{L}$ & 5 & $\mathrm{Al}$ & $1720 \mathrm{mg} / \mathrm{L}$ & 5 \\
\hline $\mathrm{B}$ & $0.983 \mathrm{mg} / \mathrm{L}$ & 71 & $\mathrm{~B}$ & $1.85 \mathrm{mg} / \mathrm{L}$ & 24 \\
\hline $\mathrm{Ba}$ & $5.70 \mathrm{mg} / \mathrm{L}$ & 5 & $\mathrm{Ba}$ & $0.058 \mathrm{mg} / \mathrm{L}$ & 12 \\
\hline $\mathrm{Ca}$ & $0.736 \mathrm{mg} / \mathrm{L}$ & 5 & $\mathrm{Ca}$ & $0.242 \mathrm{mg} / \mathrm{L}$ & 5 \\
\hline $\mathrm{Cd}$ & $0.195 \mathrm{mg} / \mathrm{L}$ & 74 & $\mathrm{Cd}$ & $0.048 \mathrm{mg} / \mathrm{L}$ & 222 \\
\hline $\mathrm{Ce}$ & $0.289 \mathrm{mg} / \mathrm{L}$ & 5 & $\mathrm{Ce}$ & $0.428 \mathrm{mg} / \mathrm{L}$ & 11 \\
\hline $\mathrm{Cr}$ & $9.71 \mathrm{mg} / \mathrm{L}$ & 5 & $\mathrm{Cr}$ & $0.311 \mathrm{mg} / \mathrm{L}$ & 85 \\
\hline $\mathrm{Cu}$ & $1.96 \mathrm{mg} / \mathrm{L}$ & 5 & $\mathrm{Cu}$ & $0.888 \mathrm{mg} / \mathrm{L}$ & 5 \\
\hline $\mathrm{Fe}$ & $256 \mathrm{mg} / \mathrm{L}$ & 5 & $\mathrm{Fe}$ & $1.09 \mathrm{mg} / \mathrm{L}$ & 5 \\
\hline $\mathrm{Gd}$ & $0.143 \mathrm{mg} / \mathrm{L}$ & 5 & $\mathrm{Gd}$ & $0.042 \mathrm{mg} / \mathrm{L}$ & 16 \\
\hline $\mathrm{K}$ & $<8.23 \mathrm{mg} / \mathrm{L}$ & N/A & $\mathrm{K}$ & $14.4 \mathrm{mg} / \mathrm{L}$ & 113 \\
\hline $\mathrm{La}$ & $0.069 \mathrm{mg} / \mathrm{L}$ & 5 & $\mathrm{La}$ & $0.081 \mathrm{mg} / \mathrm{L}$ & 18 \\
\hline $\mathrm{Li}$ & $0.052 \mathrm{mg} / \mathrm{L}$ & 9 & $\mathrm{Li}$ & $0.045 \mathrm{mg} / \mathrm{L}$ & 15 \\
\hline $\mathrm{Mg}$ & $11.2 \mathrm{mg} / \mathrm{L}$ & 5 & $\mathrm{Mg}$ & $0.027 \mathrm{mg} / \mathrm{L}$ & 6 \\
\hline $\mathrm{Mn}$ & $4.63 \mathrm{mg} / \mathrm{L}$ & 5 & $\mathrm{Mn}$ & $1.62 \mathrm{mg} / \mathrm{L}$ & 5 \\
\hline Mo & $8.05 \mathrm{mg} / \mathrm{L}$ & 5 & Mo & $4.75 \mathrm{mg} / \mathrm{L}$ & 5 \\
\hline $\mathrm{Na}$ & $367 \mathrm{mg} / \mathrm{L}$ & 5 & & $14200 \mathrm{mg} / \mathrm{L}$ & 5 \\
\hline $\mathrm{Ni}$ & $19.1 \mathrm{mg} / \mathrm{L}$ & 5 & $\mathrm{Ni}$ & $0.385 \mathrm{mg} / \mathrm{L}$ & 150 \\
\hline $\mathrm{P}$ & $3.23 \mathrm{mg} / \mathrm{L}$ & 53 & $\mathrm{P}$ & $1.82 \mathrm{mg} / \mathrm{L}$ & 47 \\
\hline $\mathrm{Pb}$ & $<0.369 \mathrm{mg} / \mathrm{L}$ & N/A & $\mathrm{Pb}$ & $<0.369 \mathrm{mg} / \mathrm{L}$ & N/A \\
\hline $\mathrm{Sb}$ & $9.97 \mathrm{mg} / \mathrm{L}$ & 5 & $\mathrm{Sb}$ & $4.91 \mathrm{mg} / \mathrm{L}$ & 5 \\
\hline $\mathrm{Sn}$ & $4.45 \mathrm{mg} / \mathrm{L}$ & 5 & $\mathrm{Sn}$ & $2.24 \mathrm{mg} / \mathrm{L}$ & 5 \\
\hline $\mathrm{Sr}$ & $0.404 \mathrm{mg} / \mathrm{L}$ & 5 & $\mathrm{Sr}$ & $0.187 \mathrm{mg} / \mathrm{L}$ & 5 \\
\hline $\mathrm{Ti}$ & $0.386 \mathrm{mg} / \mathrm{L}$ & 5 & $\mathrm{Ti}$ & $<0.014 \mathrm{mg} / \mathrm{L}$ & N/A \\
\hline $\mathrm{U}$ & $8.01 \mathrm{mg} / \mathrm{L}$ & 5 & $\mathrm{U}$ & $1.05 \mathrm{mg} / \mathrm{L}$ & 9 \\
\hline $\mathrm{Zn}$ & $3.33 \mathrm{mg} / \mathrm{L}$ & 5 & $\mathrm{Zn}$ & $1.22 \mathrm{mg} / \mathrm{L}$ & 5 \\
\hline $\mathrm{Zr}$ & $1.16 \mathrm{mg} / \mathrm{L}$ & 7 & $\mathrm{Zr}$ & $<0.280 \mathrm{mg} / \mathrm{L}$ & 28 \\
\hline
\end{tabular}


WSRC-TR-2004-00123

Revision 0

ICPES Results from B-

147 JY170C

Analytical Development Section,

SRTC, 5-5523

Calculated:

$5 / 14 / 04$

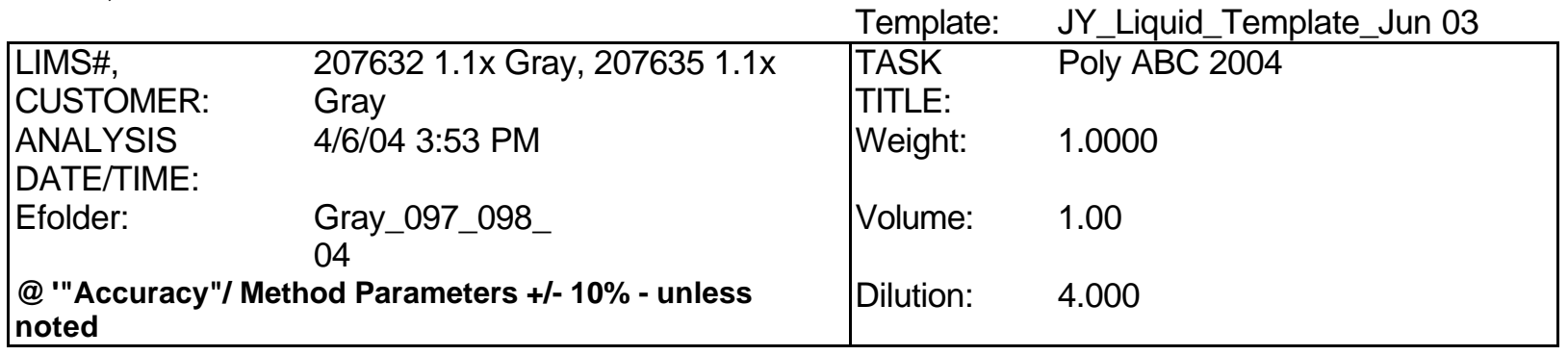

\begin{tabular}{|c|c|c|c|c|c|}
\hline \multicolumn{3}{|c|}{ HAW \#1 7Hour } & \multicolumn{3}{|c|}{ HAW \#1 24 Hour } \\
\hline Analyte & Result (x11) & $\begin{array}{c}\text { \#"Precision" } \\
\text { \%RSD }\end{array}$ & Analyte & Result (x11) & $\begin{array}{c}\text { \#"Precision" } \\
\text { \%RSD }\end{array}$ \\
\hline $\mathrm{Ag}$ & $0.018 \mathrm{mg} / \mathrm{L}$ & 35 & $\mathrm{Ag}$ & $0.025 \mathrm{mg} / \mathrm{L}$ & 18 \\
\hline $\mathrm{Al}$ & $1700 \mathrm{mg} / \mathrm{L}$ & 5 & $\mathrm{Al}$ & $1730 \mathrm{mg} / \mathrm{L}$ & 5 \\
\hline $\mathrm{B}$ & $0.623 \mathrm{mg} / \mathrm{L}$ & 65 & $\mathrm{~B}$ & $0.567 \mathrm{mg} / \mathrm{L}$ & 69 \\
\hline $\mathrm{Ba}$ & $0.047 \mathrm{mg} / \mathrm{L}$ & 21 & $\mathrm{Ba}$ & $0.055 \mathrm{mg} / \mathrm{L}$ & 11 \\
\hline $\mathrm{Ca}$ & $0.154 \mathrm{mg} / \mathrm{L}$ & 16 & $\mathrm{Ca}$ & $0.168 \mathrm{mg} / \mathrm{L}$ & 9 \\
\hline $\mathrm{Cd}$ & $0.065 \mathrm{mg} / \mathrm{L}$ & 154 & $\mathrm{Cd}$ & $0.065 \mathrm{mg} / \mathrm{L}$ & 150 \\
\hline $\mathrm{Ce}$ & $0.283 \mathrm{mg} / \mathrm{L}$ & 36 & $\mathrm{Ce}$ & $0.380 \mathrm{mg} / \mathrm{L}$ & 18 \\
\hline $\mathrm{Cr}$ & $0.255 \mathrm{mg} / \mathrm{L}$ & 100 & $\mathrm{Cr}$ & $0.237 \mathrm{mg} / \mathrm{L}$ & 113 \\
\hline $\mathrm{Cu}$ & $0.898 \mathrm{mg} / \mathrm{L}$ & 5 & $\mathrm{Cu}$ & $0.942 \mathrm{mg} / \mathrm{L}$ & 5 \\
\hline $\mathrm{Fe}$ & $0.961 \mathrm{mg} / \mathrm{L}$ & 7 & $\mathrm{Fe}$ & $0.713 \mathrm{mg} / \mathrm{L}$ & 9 \\
\hline $\mathrm{Gd}$ & $0.025 \mathrm{mg} / \mathrm{L}$ & 46 & $\mathrm{Gd}$ & $0.037 \mathrm{mg} / \mathrm{L}$ & 20 \\
\hline $\mathrm{K}$ & $11.7 \mathrm{mg} / \mathrm{L}$ & 128 & $\mathrm{~K}$ & $14.0 \mathrm{mg} / \mathrm{L}$ & 118 \\
\hline $\mathrm{La}$ & $0.062 \mathrm{mg} / \mathrm{L}$ & 28 & $\mathrm{La}$ & $0.081 \mathrm{mg} / \mathrm{L}$ & 12 \\
\hline $\mathrm{Li}$ & $<0.043 \mathrm{mg} / \mathrm{L}$ & N/A & $\mathrm{Li}$ & $0.066 \mathrm{mg} / \mathrm{L}$ & 16 \\
\hline $\mathrm{Mg}$ & $0.013 \mathrm{mg} / \mathrm{L}$ & 5 & $\mathrm{Mg}$ & $<0.010 \mathrm{mg} / \mathrm{L}$ & N/A \\
\hline $\mathrm{Mn}$ & $1.45 \mathrm{mg} / \mathrm{L}$ & 5 & $\mathrm{Mn}$ & $0.874 \mathrm{mg} / \mathrm{L}$ & 5 \\
\hline Mo & $4.62 \mathrm{mg} / \mathrm{L}$ & 7 & Mo & $4.87 \mathrm{mg} / \mathrm{L}$ & 5 \\
\hline $\mathrm{Na}$ & $14100 \mathrm{mg} / \mathrm{L}$ & 5 & $\mathrm{Na}$ & $14100 \mathrm{mg} / \mathrm{L}$ & 5 \\
\hline $\mathrm{Ni}$ & $0.374 \mathrm{mg} / \mathrm{L}$ & 147 & $\mathrm{Ni}$ & $0.373 \mathrm{mg} / \mathrm{L}$ & 157 \\
\hline $\mathrm{P}$ & $1.72 \mathrm{mg} / \mathrm{L}$ & 42 & $\mathrm{P}$ & $1.92 \mathrm{mg} / \mathrm{L}$ & 37 \\
\hline $\mathrm{Pb}$ & $<0.369 \mathrm{mg} / \mathrm{L}$ & N/A & $\mathrm{Pb}$ & $<0.369 \mathrm{mg} / \mathrm{L}$ & N/A \\
\hline $\mathrm{Sb}$ & $4.74 \mathrm{mg} / \mathrm{L}$ & 7 & $\mathrm{Sb}$ & $5.14 \mathrm{mg} / \mathrm{L}$ & 5 \\
\hline $\mathrm{Sn}$ & $2.18 \mathrm{mg} / \mathrm{L}$ & 5 & $\mathrm{Sn}$ & $2.35 \mathrm{mg} / \mathrm{L}$ & 5 \\
\hline $\mathrm{Sr}$ & $0.150 \mathrm{mg} / \mathrm{L}$ & 9 & $\mathrm{Sr}$ & $0.152 \mathrm{mg} / \mathrm{L}$ & 5 \\
\hline $\mathrm{Ti}$ & $<0.014 \mathrm{mg} / \mathrm{L}$ & N/A & $\mathrm{Ti}$ & $<0.014 \mathrm{mg} / \mathrm{L}$ & N/A \\
\hline $\mathrm{U}$ & $0.830 \mathrm{mg} / \mathrm{L}$ & 26 & $\mathrm{U}$ & $1.03 \mathrm{mg} / \mathrm{L}$ & 11 \\
\hline $\mathrm{Zn}$ & $1.18 \mathrm{mg} / \mathrm{L}$ & 5 & $\mathrm{Zn}$ & $1.25 \mathrm{mg} / \mathrm{L}$ & 5 \\
\hline $\mathrm{Zr}$ & $0.258 \mathrm{mg} / \mathrm{L}$ & 33 & $\mathrm{Zr}$ & $0.268 \mathrm{mg} / \mathrm{L}$ & 31 \\
\hline
\end{tabular}


WSRC-TR-2004-00123

Revision 0

ICPES Results from B-

147 JY170C

Analytical Development Section,

Calculated:

$5 / 14 / 04$

SRTC, 5-5523

\begin{tabular}{|c|c|c|c|}
\hline & & Template: & JY Liquid_Template Jun 03 \\
\hline $\begin{array}{l}\text { LIMS\#, } \\
\text { CUSTOMER: }\end{array}$ & 208014 4x Gray, 208020 4x Gray & $\begin{array}{l}\text { TASK } \\
\text { TITLE: }\end{array}$ & Poly ABC 2004 \\
\hline ANALYSIS & 4/21/04 1:43 & Weight: & 1.0000 \\
\hline DATE/TIME: & PM & & \\
\hline $\begin{array}{l}\text { Efolder: } \\
\text { @ "'Accuracy"/ } \\
\text { noted }\end{array}$ & $\begin{array}{l}\text { Gray_112_04 } \\
\text { thod Parameters +/- 10\% - unless }\end{array}$ & $\begin{array}{l}\text { Volume: } \\
\text { Dilution: }\end{array}$ & $\begin{array}{l}1.00 \\
4.000\end{array}$ \\
\hline
\end{tabular}

\begin{tabular}{|c|c|c|c|c|c|}
\hline \multicolumn{3}{|c|}{ HAW \#2 4 Hour } & \multicolumn{3}{|c|}{ HAW \#2 20 Hour } \\
\hline Analyte & Result (x11) & $\begin{array}{c}\text { \#"Precision" } \\
\text { \%RSD }\end{array}$ & $\underline{\text { Analyte }}$ & Result (x11) & $\begin{array}{c}\text { \#"Precision" } \\
\text { \%RSD }\end{array}$ \\
\hline $\mathrm{Ag}$ & $0.035 \mathrm{mg} / \mathrm{L}$ & 6 & $\mathrm{Ag}$ & $0.039 \mathrm{mg} / \mathrm{L}$ & 5 \\
\hline $\mathrm{Al}$ & $2310 \mathrm{mg} / \mathrm{L}$ & 5 & $\mathrm{Al}$ & $2400 \mathrm{mg} / \mathrm{L}$ & 5 \\
\hline $\mathrm{B}$ & $1.40 \mathrm{mg} / \mathrm{L}$ & 40 & $\mathrm{~B}$ & $1.53 \mathrm{mg} / \mathrm{L}$ & 36 \\
\hline $\mathrm{Ba}$ & $0.041 \mathrm{mg} / \mathrm{L}$ & 21 & $\mathrm{Ba}$ & $0.058 \mathrm{mg} / \mathrm{L}$ & 19 \\
\hline $\mathrm{Ca}$ & $0.230 \mathrm{mg} / \mathrm{L}$ & 5 & $\mathrm{Ca}$ & $0.209 \mathrm{mg} / \mathrm{L}$ & 5 \\
\hline $\mathrm{Cd}$ & $<0.052 \mathrm{mg} / \mathrm{L}$ & N/A & $\mathrm{Cd}$ & $0.056 \mathrm{mg} / \mathrm{L}$ & 385 \\
\hline $\mathrm{Ce}$ & $0.592 \mathrm{mg} / \mathrm{L}$ & 5 & $\mathrm{Ce}$ & $0.655 \mathrm{mg} / \mathrm{L}$ & 5 \\
\hline $\mathrm{Cr}$ & $0.424 \mathrm{mg} / \mathrm{L}$ & 84 & $\mathrm{Cr}$ & $0.449 \mathrm{mg} / \mathrm{L}$ & 72 \\
\hline $\mathrm{Cu}$ & $0.079 \mathrm{mg} / \mathrm{L}$ & 125 & $\mathrm{Cu}$ & $0.052 \mathrm{mg} / \mathrm{L}$ & 214 \\
\hline $\mathrm{Fe}$ & $0.132 \mathrm{mg} / \mathrm{L}$ & 158 & $\mathrm{Fe}$ & $0.102 \mathrm{mg} / \mathrm{L}$ & 198 \\
\hline $\mathrm{Gd}$ & $0.065 \mathrm{mg} / \mathrm{L}$ & 5 & $\mathrm{Gd}$ & $0.073 \mathrm{mg} / \mathrm{L}$ & 5 \\
\hline $\mathrm{La}$ & $0.120 \mathrm{mg} / \mathrm{L}$ & 5 & $\mathrm{La}$ & $0.128 \mathrm{mg} / \mathrm{L}$ & 11 \\
\hline $\mathrm{Li}$ & $<0.156 \mathrm{mg} / \mathrm{L}$ & N/A & $\mathrm{Li}$ & $<0.156 \mathrm{mg} / \mathrm{L}$ & N/A \\
\hline $\mathrm{Mg}$ & $<0.036 \mathrm{mg} / \mathrm{L}$ & N/A & $\mathrm{Mg}$ & $<0.036 \mathrm{mg} / \mathrm{L}$ & N/A \\
\hline $\mathrm{Mn}$ & $<0.020 \mathrm{mg} / \mathrm{L}$ & N/A & $\mathrm{Mn}$ & $<0.020 \mathrm{mg} / \mathrm{L}$ & N/A \\
\hline Mo & $4.18 \mathrm{mg} / \mathrm{L}$ & 6 & Mo & $4.15 \mathrm{mg} / \mathrm{L}$ & 8 \\
\hline $\mathrm{Ni}$ & $0.326 \mathrm{mg} / \mathrm{L}$ & 383 & $\mathrm{Ni}$ & $0.468 \mathrm{mg} / \mathrm{L}$ & 248 \\
\hline $\mathrm{P}$ & $3.13 \mathrm{mg} / \mathrm{L}$ & 54 & $\mathrm{P}$ & $<2.10 \mathrm{mg} / \mathrm{L}$ & N/A \\
\hline $\mathrm{Pb}$ & $<1.34 \mathrm{mg} / \mathrm{L}$ & N/A & $\mathrm{Pb}$ & $<1.34 \mathrm{mg} / \mathrm{L}$ & N/A \\
\hline $\mathrm{S}$ & $157 \mathrm{mg} / \mathrm{L}$ & 5 & $\mathrm{~S}$ & $158 \mathrm{mg} / \mathrm{L}$ & 5 \\
\hline $\mathrm{Sb}$ & $5.75 \mathrm{mg} / \mathrm{L}$ & 5 & $\mathrm{Sb}$ & $5.83 \mathrm{mg} / \mathrm{L}$ & 5 \\
\hline $\mathrm{Si}$ & $<4.83 \mathrm{mg} / \mathrm{L}$ & N/A & $\mathrm{Si}$ & $<4.83 \mathrm{mg} / \mathrm{L}$ & N/A \\
\hline Sn & $2.25 \mathrm{mg} / \mathrm{L}$ & 6 & Sn & $2.70 \mathrm{mg} / \mathrm{L}$ & 5 \\
\hline $\mathrm{Sr}$ & $0.230 \mathrm{mg} / \mathrm{L}$ & 5 & $\mathrm{Sr}$ & $0.227 \mathrm{mg} / \mathrm{L}$ & 5 \\
\hline $\mathrm{Ti}$ & $<0.052 \mathrm{mg} / \mathrm{L}$ & N/A & $\mathrm{Ti}$ & $<0.052 \mathrm{mg} / \mathrm{L}$ & N/A \\
\hline $\mathrm{U}$ & $<1.02 \mathrm{mg} / \mathrm{L}$ & N/A & $\mathrm{U}$ & $<1.02 \mathrm{mg} / \mathrm{L}$ & N/A \\
\hline $\mathrm{V}$ & $0.565 \mathrm{mg} / \mathrm{L}$ & 5 & $\mathrm{~V}$ & $0.623 \mathrm{mg} / \mathrm{L}$ & 5 \\
\hline $\mathrm{Zn}$ & 1.43 mg/L & 5 & $\mathrm{Zn}$ & $1.46 \mathrm{mg} / \mathrm{L}$ & 5 \\
\hline $\mathrm{Zr}$ & $<0.056 \mathrm{mg} / \mathrm{L}$ & N/A & $\mathrm{Zr}$ & $<0.056 \mathrm{mg} / \mathrm{L}$ & N/A \\
\hline
\end{tabular}


WSRC-TR-2004-00123

Revision 0

ICPES Results from B-

\section{JY170C}

Analytical Development Section,

Calculated:

$5 / 11 / 04,6 / 2 / 04$

SRTC, 5-5523

\begin{tabular}{|c|c|c|c|}
\hline & & Template: & JY_Liquid_Template_Jun 03 \\
\hline $\begin{array}{l}\text { LIMS\#, } \\
\text { CISTOMFR. }\end{array}$ & 208452 1.1x Gray, 208456 1.1x & TASK & Poly ABC 2004 \\
\hline ANALYSIS & Gray & TITLE: & \\
\hline $\begin{array}{l}\text { ANALYSIS } \\
\text { DATE/TIME: }\end{array}$ & b/10/04,6/2/04 & Weight: & 1.0000 \\
\hline $\begin{array}{l}\text { Efolder: } \\
\text { @ "'Accuracy"/ } \\
\text { noted }\end{array}$ & $\begin{array}{l}\text { Gray_131_04 } \\
\text { thod Parameters +/- 10\% - unless }\end{array}$ & $\begin{array}{l}\text { Volume: } \\
\text { Dilution: }\end{array}$ & $\begin{array}{l}1.00 \\
1.100\end{array}$ \\
\hline
\end{tabular}

\begin{tabular}{|c|c|c|c|c|c|}
\hline \multicolumn{3}{|c|}{ HAW \#3 Original (x11) } & \multicolumn{3}{|c|}{ HAW \#3 0 Hour $(x 55)$} \\
\hline Analyte & Result (x11) & $\begin{array}{c}\text { \#"Precision" } \\
\text { \%RSD }\end{array}$ & Analyte & Result (x11) & $\begin{array}{c}\text { \#"Precision" } \\
\text { \%RSD }\end{array}$ \\
\hline$\overline{\mathrm{Ag}}$ & $0.025 \mathrm{mg} / \mathrm{L}$ & 7 & $\mathrm{Ag}$ & $0.012 \mathrm{mg} / \mathrm{L}$ & 10 \\
\hline $\mathrm{Al}$ & $2880 \mathrm{mg} / \mathrm{L}$ & 5 & $\mathrm{Al}$ & $425 \mathrm{mg} / \mathrm{L}$ & 5 \\
\hline $\mathrm{B}$ & $3.14 \mathrm{mg} / \mathrm{L}$ & 17 & $\mathrm{~B}$ & $11.8 \mathrm{mg} / \mathrm{L}$ & 5 \\
\hline $\mathrm{Ba}$ & $0.516 \mathrm{mg} / \mathrm{L}$ & 5 & $\mathrm{Ba}$ & $0.036 \mathrm{mg} / \mathrm{L}$ & 5 \\
\hline $\mathrm{Ca}$ & $1.19 \mathrm{mg} / \mathrm{L}$ & 5 & $\mathrm{Ca}$ & $1.18 \mathrm{mg} / \mathrm{L}$ & 5 \\
\hline $\mathrm{Cd}$ & $0.061 \mathrm{mg} / \mathrm{L}$ & 158 & $\mathrm{Cd}$ & $<0.014 \mathrm{mg} / \mathrm{L}$ & N/A \\
\hline $\mathrm{Ce}$ & $<0.147 \mathrm{mg} / \mathrm{L}$ & N/A & $\mathrm{Ce}$ & $0.213 \mathrm{mg} / \mathrm{L}$ & 5 \\
\hline $\mathrm{Cr}$ & $4.17 \mathrm{mg} / \mathrm{L}$ & 6 & $\mathrm{Cr}$ & $0.060 \mathrm{mg} / \mathrm{L}$ & 109 \\
\hline $\mathrm{Cu}$ & $1.55 \mathrm{mg} / \mathrm{L}$ & 5 & $\mathrm{Cu}$ & $0.242 \mathrm{mg} / \mathrm{L}$ & 15 \\
\hline $\mathrm{Fe}$ & $22.9 \mathrm{mg} / \mathrm{L}$ & 5 & $\mathrm{Fe}$ & $0.273 \mathrm{mg} / \mathrm{L}$ & 21 \\
\hline Gd & $0.014 \mathrm{mg} / \mathrm{L}$ & 21 & Gd & $0.022 \mathrm{mg} / \mathrm{L}$ & 5 \\
\hline $\mathrm{K}$ & $<8.23 \mathrm{mg} / \mathrm{L}$ & N/A & $\mathrm{K}$ & $<8.23 \mathrm{mg} / \mathrm{L}$ & N/A \\
\hline $\mathrm{La}$ & $0.021 \mathrm{mg} / \mathrm{L}$ & 34 & $\mathrm{La}$ & $0.036 \mathrm{mg} / \mathrm{L}$ & 5 \\
\hline $\mathrm{Li}$ & $<0.043 \mathrm{mg} / \mathrm{L}$ & N/A & $\mathrm{Li}$ & $<0.043 \mathrm{mg} / \mathrm{L}$ & N/A \\
\hline $\mathrm{Mg}$ & $8.87 \mathrm{mg} / \mathrm{L}$ & 5 & $\mathrm{Mg}$ & $0.441 \mathrm{mg} / \mathrm{L}$ & 5 \\
\hline $\mathrm{Mn}$ & $93.4 \mathrm{mg} / \mathrm{L}$ & 5 & $\mathrm{Mn}$ & $0.782 \mathrm{mg} / \mathrm{L}$ & 5 \\
\hline Mo & $5.60 \mathrm{mg} / \mathrm{L}$ & 5 & Mo & $0.913 \mathrm{mg} / \mathrm{L}$ & 9 \\
\hline $\mathrm{Na}$ & $297 \mathrm{mg} / \mathrm{L}$ & 5 & & $3170 \mathrm{mg} / \mathrm{L}$ & 5 \\
\hline $\mathrm{Ni}$ & $15.0 \mathrm{mg} / \mathrm{L}$ & 5 & $\mathrm{Ni}$ & $0.118 \mathrm{mg} / \mathrm{L}$ & 243 \\
\hline $\mathrm{P}$ & $1.63 \mathrm{mg} / \mathrm{L}$ & 78 & $\mathrm{P}$ & $<0.579 \mathrm{mg} / \mathrm{L}$ & N/A \\
\hline $\mathrm{Pb}$ & $<0.369 \mathrm{mg} / \mathrm{L}$ & N/A & $\mathrm{Pb}$ & $<0.369 \mathrm{mg} / \mathrm{L}$ & N/A \\
\hline $\bar{S}$ & $<0.029 \mathrm{mg} / \mathrm{L}$ & N/A & $\bar{S}$ & $0.242 \mathrm{mg} / \mathrm{L}$ & 5 \\
\hline $\mathrm{Sb}$ & $5.95 \mathrm{mg} / \mathrm{L}$ & 5 & $\mathrm{Sb}$ & $1.00 \mathrm{mg} / \mathrm{L}$ & 5 \\
\hline $\mathrm{Si}$ & $3.95 \mathrm{mg} / \mathrm{L}$ & 5 & $\mathrm{Si}$ & $92.3 \mathrm{mg} / \mathrm{L}$ & 5 \\
\hline $\mathrm{Sn}$ & $1.91 \mathrm{mg} / \mathrm{L}$ & 5 & $\mathrm{Sn}$ & $0.675 \mathrm{mg} / \mathrm{L}$ & 5 \\
\hline $\mathrm{Sr}$ & $0.421 \mathrm{mg} / \mathrm{L}$ & 5 & $\mathrm{Sr}$ & $0.285 \mathrm{mg} / \mathrm{L}$ & 5 \\
\hline $\mathrm{Ti}$ & $0.310 \mathrm{mg} / \mathrm{L}$ & 5 & Ti & $0.058 \mathrm{mg} / \mathrm{L}$ & 5 \\
\hline $\mathrm{U}$ & $1.05 \mathrm{mg} / \mathrm{L}$ & 7 & $\mathrm{U}$ & $0.491 \mathrm{mg} / \mathrm{L}$ & 26 \\
\hline N/A & N/A & N/A & $\mathrm{V}$ & $0.140 \mathrm{mg} / \mathrm{L}$ & 5 \\
\hline $\mathrm{Zn}$ & $3.61 \mathrm{mg} / \mathrm{L}$ & 5 & $\mathrm{Zn}$ & $0.564 \mathrm{mg} / \mathrm{L}$ & 5 \\
\hline $\mathrm{Zr}$ & $1.25 \mathrm{mg} / \mathrm{L}$ & 29 & $\mathrm{Zr}$ & $0.254 \mathrm{mg} / \mathrm{L}$ & 28 \\
\hline
\end{tabular}


WSRC-TR-2004-00123

Revision 0

ICPES Results from B-

\section{JY170C}

Analytical Development Section,

Calculated:

$6 / 2 / 04$

SRTC, 5-5523

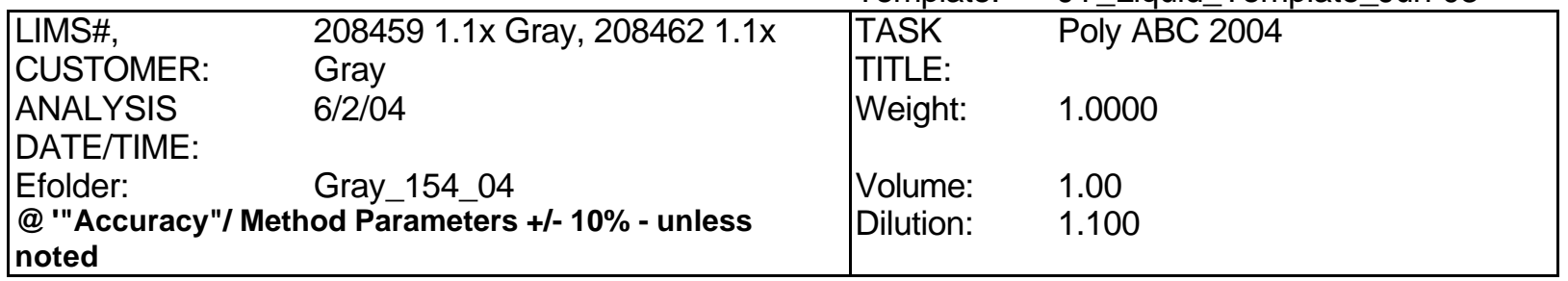

\begin{tabular}{|c|c|c|c|c|c|}
\hline \multicolumn{3}{|c|}{ HAW \#3 3.5 Hour $(x 11)$} & \multicolumn{3}{|c|}{ HAW \#3 20.5 Hour $(x 11)$} \\
\hline Analyte & Result (x11) & $\begin{array}{c}\text { \#"Precision" } \\
\text { \%RSD }\end{array}$ & Analyte & Result (x11) & $\begin{array}{c}\text { \#"Precision" } \\
\text { \%RSD }\end{array}$ \\
\hline $\mathrm{Ag}$ & $0.047 \mathrm{mg} / \mathrm{L}$ & 7 & $\mathrm{Ag}$ & $0.040 \mathrm{mg} / \mathrm{L}$ & 5 \\
\hline $\mathrm{Al}$ & $1890 \mathrm{mg} / \mathrm{L}$ & 5 & $\mathrm{Al}$ & $1890 \mathrm{mg} / \mathrm{L}$ & 5 \\
\hline $\mathrm{B}$ & $11.7 \mathrm{mg} / \mathrm{L}$ & 5 & $\mathrm{~B}$ & $11.6 \mathrm{mg} / \mathrm{L}$ & 5 \\
\hline $\mathrm{Ba}$ & $0.084 \mathrm{mg} / \mathrm{L}$ & 5 & $\mathrm{Ba}$ & $0.071 \mathrm{mg} / \mathrm{L}$ & 5 \\
\hline $\mathrm{Ca}$ & $1.23 \mathrm{mg} / \mathrm{L}$ & 5 & $\mathrm{Ca}$ & $1.53 \mathrm{mg} / \mathrm{L}$ & 5 \\
\hline $\mathrm{Cd}$ & $0.059 \mathrm{mg} / \mathrm{L}$ & 147 & $\mathrm{Cd}$ & $0.052 \mathrm{mg} / \mathrm{L}$ & 151 \\
\hline $\mathrm{Ce}$ & $0.771 \mathrm{mg} / \mathrm{L}$ & 8 & $\mathrm{Ce}$ & $0.685 \mathrm{mg} / \mathrm{L}$ & 5 \\
\hline $\mathrm{Cr}$ & $0.327 \mathrm{mg} / \mathrm{L}$ & 53 & $\mathrm{Cr}$ & $0.273 \mathrm{mg} / \mathrm{L}$ & 67 \\
\hline $\mathrm{Cu}$ & $0.675 \mathrm{mg} / \mathrm{L}$ & 6 & $\mathrm{Cu}$ & $0.648 \mathrm{mg} / \mathrm{L}$ & 6 \\
\hline $\mathrm{Fe}$ & $0.651 \mathrm{mg} / \mathrm{L}$ & 10 & $\mathrm{Fe}$ & $0.250 \mathrm{mg} / \mathrm{L}$ & 27 \\
\hline Gd & $0.075 \mathrm{mg} / \mathrm{L}$ & 8 & Gd & $0.068 \mathrm{mg} / \mathrm{L}$ & 5 \\
\hline $\mathrm{K}$ & $46.2 \mathrm{mg} / \mathrm{L}$ & 43 & $\mathrm{~K}$ & $49.9 \mathrm{mg} / \mathrm{L}$ & 42 \\
\hline $\mathrm{La}$ & $0.118 \mathrm{mg} / \mathrm{L}$ & 6 & $\mathrm{La}$ & $0.108 \mathrm{mg} / \mathrm{L}$ & 5 \\
\hline $\mathrm{Li}$ & $0.103 \mathrm{mg} / \mathrm{L}$ & 15 & $\mathrm{Li}$ & $0.087 \mathrm{mg} / \mathrm{L}$ & 5 \\
\hline $\mathrm{Mg}$ & $0.542 \mathrm{mg} / \mathrm{L}$ & 5 & $\mathrm{Mg}$ & $0.404 \mathrm{mg} / \mathrm{L}$ & 5 \\
\hline $\mathrm{Mn}$ & $5.39 \mathrm{mg} / \mathrm{L}$ & 5 & $\overline{\mathrm{Mn}}$ & $1.55 \mathrm{mg} / \mathrm{L}$ & 5 \\
\hline Mo & $3.98 \mathrm{mg} / \mathrm{L}$ & 5 & Mo & $4.10 \mathrm{mg} / \mathrm{L}$ & 5 \\
\hline $\mathrm{Na}$ & $13700 \mathrm{mg} / \mathrm{L}$ & 5 & $\mathrm{Na}$ & $13600 \mathrm{mg} / \mathrm{L}$ & 5 \\
\hline $\mathrm{Ni}$ & $0.649 \mathrm{mg} / \mathrm{L}$ & 80 & $\mathrm{Ni}$ & $0.426 \mathrm{mg} / \mathrm{L}$ & 112 \\
\hline $\mathrm{P}$ & $<0.579 \mathrm{mg} / \mathrm{L}$ & N/A & $\mathrm{P}$ & $<0.579 \mathrm{mg} / \mathrm{L}$ & N/A \\
\hline $\mathrm{Pb}$ & $<0.369 \mathrm{mg} / \mathrm{L}$ & N/A & $\mathrm{Pb}$ & $<0.369 \mathrm{mg} / \mathrm{L}$ & N/A \\
\hline $\mathrm{S}$ & $0.795 \mathrm{mg} / \mathrm{L}$ & 5 & $\mathrm{~S}$ & $0.768 \mathrm{mg} / \mathrm{L}$ & 5 \\
\hline $\mathrm{Sb}$ & $4.60 \mathrm{mg} / \mathrm{L}$ & 5 & $\mathrm{Sb}$ & $4.51 \mathrm{mg} / \mathrm{L}$ & 5 \\
\hline $\mathrm{Si}$ & $98.6 \mathrm{mg} / \mathrm{L}$ & 5 & $\mathrm{Si}$ & $101 \mathrm{mg} / \mathrm{L}$ & 5 \\
\hline $\mathrm{Sn}$ & $2.02 \mathrm{mg} / \mathrm{L}$ & 5 & $\mathrm{Sn}$ & $1.91 \mathrm{mg} / \mathrm{L}$ & 5 \\
\hline $\mathrm{Sr}$ & $0.384 \mathrm{mg} / \mathrm{L}$ & 9 & $\mathrm{Sr}$ & $0.448 \mathrm{mg} / \mathrm{L}$ & 5 \\
\hline $\mathrm{Ti}$ & $0.852 \mathrm{mg} / \mathrm{L}$ & N/A & Ti & $0.202 \mathrm{mg} / \mathrm{L}$ & 5 \\
\hline $\mathrm{U}$ & $1.64 \mathrm{mg} / \mathrm{L}$ & 6 & $\overline{\mathrm{U}}$ & $1.46 \mathrm{mg} / \mathrm{L}$ & 5 \\
\hline $\mathrm{V}$ & $0.650 \mathrm{mg} / \mathrm{L}$ & 5 & $\mathrm{~V}$ & $0.634 \mathrm{mg} / \mathrm{L}$ & 5 \\
\hline $\mathrm{Zn}$ & $2.41 \mathrm{mg} / \mathrm{L}$ & 5 & $\mathrm{Zn}$ & $2.34 \mathrm{mg} / \mathrm{L}$ & 5 \\
\hline $\mathrm{Zr}$ & $0.303 \mathrm{mg} / \mathrm{L}$ & 26 & $\mathrm{Zr}$ & $0.264 \mathrm{mg} / \mathrm{L}$ & 30 \\
\hline
\end{tabular}

